\title{
Interaction Between the Complement System and Infectious Agents - A Potential Mechanistic Link to Neurodegeneration and Dementia
}

OPEN ACCESS

Edited by:

Marco Bacigaluppi,

San Raffaele Scientific Institute

(IRCCS), Italy

Reviewed by:

Faith H. Brennan,

The Ohio State University,

United States

Judith Fraussen,

Hasselt University, Belgium

*Correspondence: Noriko Shinjyo

nshinjyo@ifrec.osaka-u.ac.jp

Specialty section:

This article was submitted to

Cellular Neuropathology,

a section of the journal

Frontiers in Cellular Neuroscience

Received: 16 May 2021

Accepted: 09 July 2021

Published: 02 August 2021

Citation:

Shinjyo N, Kagaya W and Pekna M (2021) Interaction Between

the Complement System and Infectious Agents - A Potential Mechanistic Link

to Neurodegeneration and Dementia. Front. Cell. Neurosci. 15:710390. doi: 10.3389/fncel.2021.710390

\begin{abstract}
Noriko Shinjyo ${ }^{1,2 *}$, Wataru Kagaya ${ }^{3}$ and Marcela Pekna ${ }^{4,5}$
${ }^{1}$ Laboratory of Immune Homeostasis, WPI Immunology Frontier Research Center, Osaka University, Osaka, Japan, ${ }^{2}$ School of Tropical Medicine and Global Health, Nagasaki University, Nagasaki, Japan, ${ }^{3}$ Department of Parasitology and Research Center for Infectious Disease Sciences, Graduate School of Medicine, Osaka City University, Osaka, Japan, ${ }^{4}$ Laboratory of Regenerative Neuroimmunology, Center for Brain Repair, Department of Clinical Neuroscience, Institute of Neuroscience and Physiology, Sahlgrenska Academy at the University of Gothenburg, Gothenburg, Sweden, ${ }^{5}$ Florey Institute

of Neuroscience and Mental Health, Parkville, VIC, Australia
\end{abstract}

As part of the innate immune system, complement plays a critical role in the elimination of pathogens and mobilization of cellular immune responses. In the central nervous system (CNS), many complement proteins are locally produced and regulate nervous system development and physiological processes such as neural plasticity. However, aberrant complement activation has been implicated in neurodegeneration, including Alzheimer's disease. There is a growing list of pathogens that have been shown to interact with the complement system in the brain but the short- and long-term consequences of infection-induced complement activation for neuronal functioning are largely elusive. Available evidence suggests that the infection-induced complement activation could be protective or harmful, depending on the context. Here we summarize how various infectious agents, including bacteria (e.g., Streptococcus spp.), viruses (e.g., HIV and measles virus), fungi (e.g., Candida spp.), parasites (e.g., Toxoplasma gondii and Plasmodium spp.), and prion proteins activate and manipulate the complement system in the CNS. We also discuss the potential mechanisms by which the interaction between the infectious agents and the complement system can play a role in neurodegeneration and dementia.

Keywords: complement, infection, dementia, Alzheimer's disease, inflammation

\section{INTRODUCTION}

\section{The Complement System}

The complement system is an evolutionarily conserved proteolytic cascade, consisting of over 40 components (Schartz and Tenner, 2020). Complement plays a key role as part of the innate immunity, eliminating pathogens and damaged cells, directly killing bacteria by forming the so-called membrane attack complex (MAC), and promoting inflammatory responses via the generation of anaphylatoxins (Yanamadala and Friedlander, 2010). The activation of the complement system can be triggered via three pathways: the classical pathway, the lectin pathway, and the alternative pathway (Veerhuis et al., 2011; Figure 1).

Each of the activation pathways leads to the formation of $\mathrm{C} 3$ convertase $(\mathrm{C} 4 \mathrm{bC} 2 \mathrm{~b}$ or $\mathrm{C} 3 \mathrm{bBb})$ that cleaves the third complement component (C3) into the $\mathrm{C} 3 \mathrm{a}$ and $\mathrm{C} 3 \mathrm{~b}$ fragments, the latter of which 
functions as an opsonin, forms the C3 convertase of the alternative pathway $(\mathrm{C} 3 \mathrm{bBb})$ and takes part in the next step of the activation cascade, i.e., proteolytic cleavage of C5. C5 activation results in the release of $\mathrm{C} 5 \mathrm{a}$ and the formation of MAC, a.k.a. the terminal complement complex, C5b-9. C3a and $\mathrm{C} 5 \mathrm{a}$ are peptides with anaphylatoxin properties and function as fluid-phase inflammatory mediators. They exert their biological effects mainly through the cognate membrane-bound receptors $\mathrm{C} 3 \mathrm{a}$ receptor $(\mathrm{C} 3 \mathrm{aR})$ and $\mathrm{C} 5 \mathrm{a}$ receptor $(\mathrm{C} 5 \mathrm{aR} 1)$, respectively. $\mathrm{C} 5 \mathrm{a}$ can also bind to the second C5a-like receptor (C5L2, $\mathrm{C} 5 \mathrm{aR} 2)$. C5aR1 can propagate proinflammatory signals to induce cytokine/chemokine release and mediate the chemoattraction and activation of neutrophils and macrophages (Mathern and Heeger, 2015). C3aR signaling is immunomodulatory, exerting pro- or anti-inflammatory effects in a context-dependent manner (Coulthard and Woodruff, 2015). For example, C3aR activation enhances phagocytosis by macrophages (Wu et al., 2019) and suppresses injury-induced mobilization of neutrophils (Wu et al., 2013; Brennan et al., 2019). Besides its C3aR-mediated actions, C3a has a direct anti-microbial activity (Pasupuleti et al., 2007), indicating its multiple modes of action as an anti-infective agent. Even without antibodies, complement can neutralize pathogens (Speth et al., 2002). In addition, there are links between complement and adaptive immunity, such as the robust augmentation of antibody responses mediated by the C3d fragment (proteolytically generated from C3b) and complement receptor 2 (CR2) (Dempsey et al., 1996) and the regulation of $\mathrm{T}$ cell activation by C3a/C5a (Lalli et al., 2008). Thus, the complement system has crucial functions in both innate and adaptive immune responses (Mathern and Heeger, 2015). In addition, recent reports show that a number of cell types store intracellular C3 (Elvington et al., 2016), which has been proposed to have an important role in the regulation of cellular homeostasis (Liszewski et al., 2017). For example, cathepsin L-mediated intracellular C3 cleavage and C3a generation are required for homeostatic T cell survival (Liszewski et al., 2013). Airway epithelial cells can de novo synthesize C3, and intracellular C3 protects these cells from stress-induced cell death (Kulkarni et al., 2019). Intracellular C3 is also required for autophagic turnover of pancreatic $\beta$ cells during diabetic stress (King et al., 2019). Notably, C3 is an evolutionarily ancient protein; it is considered to be the first element of the original complement system, whose primary role was to guard intracellular environment and homeostasis from various stimuli (Elvington et al., 2016). While complement is widely acknowledged as part of vertebrate humoral immunity, the significance of intracellular complement is less recognized. The potential role for intracellular C3 in self-defense against infection warrants further investigation.

The classical pathway is initiated by binding of $\mathrm{Cl}$ (C1qrs) to activators such as immune complexes, microbes, apoptotic cells, and some specific proteins including fibrillar amyloid $\beta(\mathrm{A} \beta)$ (Veerhuis et al., 2011). The lectin pathway is activated by binding of mannose-binding lectin (MBL) and ficolin to carbohydrates on microorganisms or dying cells (Veerhuis et al., 2011). The classical and lectin pathways converge at the proteolytic cleavage of $\mathrm{C} 4$ and $\mathrm{C} 2$ and the formation of $\mathrm{C} 4 \mathrm{bC} 2 \mathrm{~b}$, the $\mathrm{C} 3$ convertase shared by these pathways. The alternative pathway continuously generates low levels of C3-derived activation products and C3 convertase $\mathrm{C} 3 \mathrm{bBb}$, providing a natural immunity to microbes (Farriesa and Atkinson, 1991). The activation of alternative pathway can also occur as a result of direct interaction between $\mathrm{C} 3 \mathrm{~b}$ and pathogenic molecules, including fibrillar $\mathrm{A} \beta$, further amplifying the downstream of complement cascade (Tenner, 2020). C3 and C5 can be cleaved also by MASP 1 (Matsushita and Fujita, 1995), neutrophil elastase (Yuan et al., 2015), cathepsins (Liszewski et al., 2013; Yuan et al., 2015), granulocyte proteases (Johnson et al., 1976), lysosomal enzymes, kallikrein, coagulation factors XIa, Xa, IXa, thrombin, and plasmin (Markiewski and Lambris, 2007; Amara et al., 2010). This non-convertase mode of activation is also called the extrinsic pathway.

Under physiological conditions, complement activity is tightly regulated by regulators of complement activation (RCA) to safeguard against autologous tissue injury. The RCAs that limit complement activation both in time and space include factor $\mathrm{H}(\mathrm{FH})$, factor I, C1-inhibitor, C4-binding protein, clusterin, vitronectin, CD46 (membrane cofactor protein, MCP), CD55 (decay accelerating factor, DAF), and complement receptor 1 (CR1, CD35). Properdin (FP), on the other hand, acts as a positive regulator that stabilizes the alternative pathway $\mathrm{C} 3$ convertase (Figure 1).

\section{The Complement System in the CNS}

Although the liver is the major source of circulating soluble complement proteins (Perlmutter and Colten, 1986), it is now established that complement components are locally synthesized throughout the body, including the brain (Woodruff et al., 2010; Tenner et al., 2018). Complement proteins, including the regulatory factors and receptors, are produced by glia and neurons (Gasque et al., 1998; Ischenko et al., 1998; Nataf et al., 1999), and recent studies have revealed a range of nonimmune functions of the complement system in the CNS. For example, complement deposition on synapses, followed by CR3-dependent microglial engulfment and elimination of C1qand $\mathrm{C} 3 \mathrm{~b} / \mathrm{iC} 3 \mathrm{~b}$-tagged synapses, plays a crucial role in synaptic pruning during normal development (Schafer et al., 2012). C3aR and $\mathrm{C} 5 \mathrm{aR}$ are expressed by neurons and glia in the brain under normal and pathological conditions (Barnum et al., 2002). C3aR signaling regulates neuronal migration during CNS development (Gorelik et al., 2017), controls neural progenitor cell proliferation (Coulthard et al., 2018), differentiation and migration in vitro (Shinjyo et al., 2009), and promotes basal as well as injuryinduced neurogenesis in the adult mouse brain (Rahpeymai et al., 2006; Shinjyo et al., 2009; Stokowska and Pekna, 2018). Notably, mice lacking C3 exhibit excessive number of synapses as young adults (Stevens et al., 2007; Perez-Alcazar et al., 2014) and neuronal migration defects characteristic of autism spectrum disorder (Gorelik et al., 2017), and are protected against agerelated loss of synapses in the hippocampus (Shi et al., 2015). Higher expression of $\mathrm{C} 4$ in the brain has been implicated in excessive loss of synapses and development of schizophrenia (Sekar et al., 2016). C3aR deficiency is associated with altered morphology of the hippocampus and amygdala, mild cognitive impairment and hyperactive behavior in unchallenged mice (Coulthard et al., 2018; Pozo-Rodrigálvarez et al., 2021) as well 


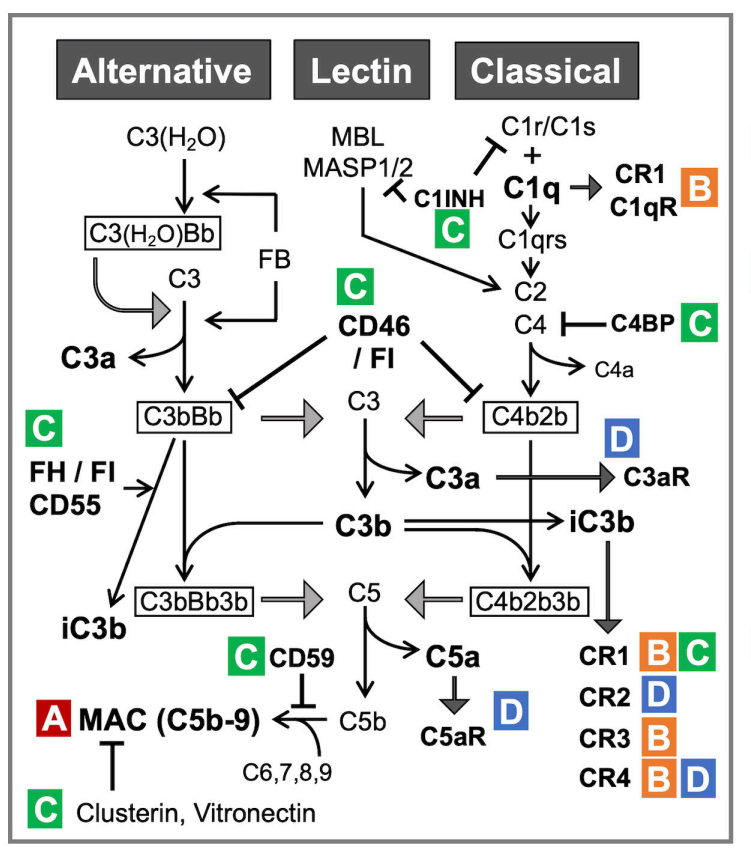

\section{Functions \\ A Cell lysis \\ Killing of pathogens \\ B Opsonization / Phagocytosis \\ - Clearance of apoptotic cells and debris (CR1/CR3/CR4/C1qR) \\ - Synaptic pruning (CR3)}

\section{Regulation}

Inhibition of the complement cascade

\section{Other functions}

- Promotion of cell differentiation and recruitment (C3aR/C5aR)

-Modulation of immune cell migration (C3aR)

- Regulation of B-cell functions (CR2)

- Leukocyte adhesion (CR4)

FIGURE 1 | The complement system: activation pathways and functions in the CNS. All three pathways converge at C3. The formation of C3 convertase $\left[\mathrm{C} 3\left(\mathrm{H}_{2} \mathrm{O}\right) \mathrm{Bb}\right.$ and $\mathrm{C} 3 \mathrm{bBb}$ in the alternative pathway or $\mathrm{C} 4 \mathrm{~b} 2 \mathrm{~b}$ in the classical and lectin pathways], followed by $\mathrm{C} 3$ cleavage, leads to the formation of MAC, the terminal complement complex (A). C1q and iC3b also facilitate immune responses via opsonization and promoting phagocytosis through binding to the receptors (CR1 and C1qR for C1q; CR1, CR2, and CR3 for iC3b) (B). Under physiological conditions, complement activation is tightly controlled by the regulators of complement activation (RCAs) (C). C3a and C5a, the smaller fragments generated through the proteolytic activation of C3 and C5, respectively, regulate differentiation and mobilization of immune and non-immune cells through the cognate receptors C3aR and C5aR, respectively (D). C3 and C5 can be also cleaved by other proteases via the so-called extrinsic pathway. C1qR, C1q receptor; C3bBb3b, $\mathrm{C} 5$ convertase formed by binding of additional $\mathrm{C} 3 \mathrm{~b}$ to $\mathrm{C} 3 \mathrm{bBb}$ (C3 convertase); $\mathrm{C} 3\left(\mathrm{H}_{2} \mathrm{O}\right)$, hydrated $\mathrm{C} 3$; $\mathrm{C} 3\left(\mathrm{H}_{2} \mathrm{O}\right) \mathrm{Bb}$, the initiating $\mathrm{C} 3$ convertase of alternative pathway, consisting of $\mathrm{C}_{3}\left(\mathrm{H}_{2} \mathrm{O}\right)$ and $\mathrm{Bb}$ (Factor $\mathrm{B}[\mathrm{FB}]$ cleavage product); CR1, complement receptor type 1; CR2, complement receptor type 2; CR3, complement receptor type 3; CR4, complement receptor type 4; FH, complement factor $\mathrm{H}$; Fl, complement factor I. C4BP, C4-binding protein; C1INH, C1-inhibitor.

as reduced neural plasticity responses after ischemic brain injury (Stokowska et al., 2017). Thus, the complement system is required for the normal development and function of the CNS.

Considering the broad range of neurodevelopmental and neuroregulatory functions of complement in the brain, it is not surprising that dysfunction or aberrant activation of the complement system have been implicated in the pathogenesis of a number of brain disorders (Gasque et al., 2000; Morgan, 2015). More specifically, complement activation has been observed in human neurodegenerative diseases, such as Alzheimer's disease $(\mathrm{AD})$, prion disease, chromosome 13 dementias (Eikelenboom et al., 2002; Rostagno et al., 2002; Morgan, 2018), as well as other neurological disorders associated with the blood-brain barrier (BBB) dysfunctions such as cerebrovascular disease, multiple sclerosis (MS) (Storch et al., 1998), and meningitis (Koelman et al., 2019). In infection, while providing protection against pathogens, excessive or prolonged activation of the complement system can lead to exaggerated inflammation and unfavorable outcomes (Ross and Densen, 1984; Figure 1).

\section{Complement and Dementia}

Dementia is a broad term for conditions with progressive memory impairment, executive and behavioral anomaly, and emotional problems, affecting the ability to perform day-to-day activities. Complement activation is implicated in $\mathrm{AD}$, the most prevalent form of dementia (Rubio-Perez and Morillas-Ruiz, 2012). Together with glial activation and pro-inflammatory cytokine release, complement activation occurs during the early stage of the disease progression (Aiyaz et al., 2012). As described above, amyloid proteins stimulate complement activity (Veerhuis et al., 2011; Tenner, 2020), leading to the activation of the surrounding glial cells and local chronic inflammation (Cadman and Puttfarcken, 1997; Veerhuis et al., 2011). Complement proteins are present in amyloid plaques in the brain (Aiyaz et al., 2012), and co-localize with $A \beta$ in the brain capillaries of cerebral amyloid angiopathy (Matsuo et al., 2017), suggesting that complement activation is a key event associated with amyloid deposition. In addition, complement is likely involved in other forms of dementia, including chromosome 13 dementias (familial British dementia FBD and familial Danish dementia FDD). Similar to AD, chromosome 13 dementias are associated with neurodegeneration and amyloid deposition in the CNS. In spite of the structural differences in the disease-associated amyloid proteins $(\mathrm{A} \beta$ in $\mathrm{AD}, \mathrm{ABri}$ in $\mathrm{FBD}$, $\mathrm{ADan}$ in FDD), neurodegeneration and amyloid deposition, associated with glial activation and local inflammation, are the common hallmark in all of these dementias (Saul et al., 2013). Importantly, complement activation products co-localize with 
amyloid plaques and related deposits in FBD and FDD (Rostagno et al., 2002). ABri and ADan synthetic peptides activate classical and alternative complement pathways, leading to the formation of the terminal complex (C5b-9). These data suggest that chronic complement activation associated with amyloid deposits may be a contributing factor to dementia progression in chromosome 13 dementias as well as in $\mathrm{AD}$. While experimental evidence points to the critical function of complement in $A \beta$ clearance (WyssCoray et al., 2002), and C3- and CR3-dependent microglial phagocytosis appears to play a beneficial role in the elimination of foreign pathogens as well as $A \beta$ (Fu et al., 2012), CR3 also limits $A \beta$ clearance from the brain interstitial fluid (Czirr et al., 2017), and is involved in A $\beta$-induced microglia-mediated loss of synapses in AD (Hong et al., 2016). The complexity of the involvement of complement in $\mathrm{AD}$ type of neurodegeneration is further highlighted by findings in the C3 deficient mice carrying the $\mathrm{AD}$-associated mutations in the amyloid polypeptide and presenilin 1 genes. In this model, the C3 deficiency was protective against plaque-related synapse and neuron loss as well as cognitive decline, despite higher plaque burden (Shi et al., 2017). In addition, C1q and CR3 are required for the clearance of neuronal debris by microglia, at least in the context of injury-induced neurodegeneration (Norris et al., 2018). By virtue of its proinflammatory functions, C5a plays a significant role in neurodegeneration, including AD (Landlinger et al., 2015). Jointly, these reports point to the role of the complement system in $A \beta$ and debris clearance as well as synapse elimination, $A \beta$ induced neurodegeneration and dementia.

\section{Complement and Brain Infection}

In the presence of an intact BBB, circulating immune cells, such as B- and T-lymphocytes, have limited access to the CNS. As a result, the defense of brain tissue against invading pathogens is largely dependent on local innate immunity, in particular the complement system. A number of pathogens escape the peripheral immune responses and enter the CNS. The interaction between pathogens and complement can lead to the clearance of pathogens, however, it may also contribute to tissue damage. Here we summarize the interactions between complement and infectious organisms, including bacteria, viruses, fungi, and parasites (Table 1), and discuss the potential impact of these interactions on CNS function. The interactions between complement and prion proteins are also discussed.

\section{INTERACTIONS BETWEEN INFECTIOUS AGENTS AND COMPLEMENT IN THE CNS}

\section{Bacteria}

Genetic defects in the complement system increase the susceptibility to bacterial infection (Brouwer et al., 2009). $\mathrm{C} 2$, factor D (FD), and FP deficiencies are associated with predisposition to meningococcal disease (Fijen et al., 1999; Jönsson et al., 2005; Sprong et al., 2006), while singlenucleotide polymorphisms (SNPs) in MBL are associated with pneumococcal disease (Brouwer et al., 2009). FH genotype $496 \mathrm{C} / \mathrm{C}$ is associated with meningococcal disease (Haralambous et al., 2006) as is a locus in the FH (CFH) region (Davila et al., 2010). C3a exhibits anti-microbial activity against Gram-negative and Gram-positive bacteria (Pasupuleti et al., 2007). These data show that complement-dependent immune response is crucial in the protection against bacterial infection.

The evidence for the involvement of the complement system in bacterial meningitis is summarized in Table 1.1. Bacterial meningitis is an acute inflammation caused by infection in the meninges that envelope and protect the brain and spinal cord. Commonly caused by Streptococcus pneumoniae, Neisseria meningitidis, and Listeria monocytogenes, bacterial meningitis is a major health threat, the morbidity and mortality of which are driven by dysregulated host immune reactions (Mook-Kanamori et al., 2011; van de Beek et al., 2016).

As the long-term sequelae of bacterial meningitis include cognitive impairment, infection-induced inflammation may have lasting or even permanent impact on brain function (van de Beek et al., 2004), and there is strong experimental and clinical evidence for the detrimental role of complement in meningitis. Inhibition of the classical pathway and of C5 were both protective against meningitis caused by $S$. pneumoniae in rodents (Zwijnenburg et al., 2007; Woehrl et al., 2011), and a single nucleotide polymorphism of C5 (rs17611, encoding V802I) was associated with poor outcome in pneumococcal meningitis patients (Woehrl et al., 2011), indicating that the activation of the classical complement pathway plays a key role in the pathogenesis. In murine bacterial meningitis model, $L$. monocytogenes infection caused the up-regulation of $\mathrm{C} 3$ and FB mRNA levels in the cerebrospinal fluid (CSF) as well as in parenchymal neurons (Stahel et al., 1997), implicating local activation of the alternative pathway in the brain during meningitis. C3aR is up-regulated in glial cells and infiltrating immune cell populations in the brain tissue autopsy from bacterial meningitis patients (Gasque et al., 1998), and C5aR deficient mice were less susceptible to meningitis development despite unaltered bacterial titers in the brain (Woehrl et al., 2011), suggesting the important roles for anaphylatoxin receptor signaling in infection-induced neuroinflammation.

$\mathrm{FH}$ and $\mathrm{CD} 46$, the negative regulators of the complement system, contribute to or even enable of bacterial dissemination into the CNS. FH binding protein (Fhb) is a meningococcal protein that binds to human $\mathrm{FH}$. The interaction between Fhb and host $\mathrm{FH}$ enables the bacteria to evade the innate immune attack, thereby facilitating systemic dissemination. Streptococcus suis, a zoonotic bacterium causing bacterial meningitis (Dominguez-Punaro et al., 2007), expresses Fhb, which contributes to the $S$. suis virulence via inhibition of C3b/iC3b deposition on the bacterial surface (Pian et al., 2012). In addition, Fhb can contribute to the development of severe meningitis by enhancing the traversal of $S$. suis across the BBB, as suggested by in vivo and in vitro experiments (Kong et al., 2017). Similarly, CD46 acts as the entry receptor for a number of microbes, including N. meningitidis, an exclusively human pathogen. While CD46 is ubiquitously expressed in human tissues, it is only expressed in the eye and spermatozoa in mouse 
TABLE 1.1 | Interactions between complement and bacteria in the CNS.

\begin{tabular}{|c|c|c|c|c|c|}
\hline & Pathogen & Study design & Outcomes & Conclusion(s) & References \\
\hline 1 & $\begin{array}{l}\text { Staphylococcus } \\
\text { epidermidis }\end{array}$ & $\begin{array}{l}\text { (in vivo) Neonatal infection and } \\
\text { sepsis model in preterm pigs, } \\
\text { induced by systemic infection } \\
\text { with } S \text {. epidermidis. }\end{array}$ & $\begin{array}{l}\text { (1) S. epidermidis inoculation caused } \\
\text { sepsis and blood CSF barrier disruption } \\
\text { in preterm pigs. } \\
\text { (2) Acute-phase immune response } \\
\text { proteins, including complement } \\
\text { proteins (C1r, C3, and } \mathbf{C 5} \text { ), were } \\
\text { up-regulated in CSF at } 24 \mathrm{~h} \\
\text { post-infection. }\end{array}$ & $\begin{array}{l}\text { S. epidermidis systemic } \\
\text { infection increased the levels of } \\
\mathbf{C 1 r}, \mathbf{C} 3 \text {, and } \mathbf{C 5} \text { in the CSF. }\end{array}$ & $\begin{array}{l}\text { Muk et al., } \\
2019\end{array}$ \\
\hline 2 & Streptococcus suis & $\begin{array}{l}\text { (1) (in vitro) Human BBB model } \\
\text { using hCMEC/D3 and S. suis } \\
\text { (WT, Fhb deficient) } \\
\text { (2) (in vivo) Murine model of } \\
\text { S. suis meningitis. } \\
\text { WT vs. Gb3* deficient mice. } \\
\text { *The receptor for S. suis Fhb. }\end{array}$ & $\begin{array}{l}\text { 1-(1) BBB traversal efficiency of S. suis } \\
\text { was reduced by Factor } \mathbf{H} \text { binding } \\
\text { protein (Fhb) deficiency and } \mathbf{F h b} \\
\text { antibody. } \\
\text { 1-(2) Gb3 synthesis inhibition reduced } \\
\text { adherence of } S \text {. suis to hCMEC/D3. } \\
\text { (2) Gb3 deficiency was protective } \\
\text { against meningitis. }\end{array}$ & $\begin{array}{l}\text { Fhb facilitates BBB invasion } \\
\text { and traversal. }\end{array}$ & $\begin{array}{l}\text { Kong et al., } \\
2017\end{array}$ \\
\hline 3 & $\begin{array}{l}\text { Streptococcus } \\
\text { pneumoniae }\end{array}$ & $\begin{array}{l}\text { Pneumococcal meningitis } \\
\text { (1) (Human) nationwide } \\
\text { prospective cohort study of } \\
\text { adults with } \\
\text { community-acquired bacterial } \\
\text { meningitis (n636) vs. control } \\
\text { (partners or non-related proxies } \\
\text { living in the same dwelling). } \\
\text { (2) (in vivo) C5aR deficient } \\
\text { mice. }\end{array}$ & $\begin{array}{l}\text { 1-(1) C5 genotype rs } 17611 \text { was } \\
\text { associated with worse outcome in } \\
\text { pneumococcal meningitis patients (OR } \\
2.25 ; 95 \% \mathrm{Cl} 1.33-3.81 ; P=0.002) \text {. } \\
\text { Patients with rs17611 GG genotype) } \\
\text { had lower CSF WBC counts. } \\
\text { 1-(2) C5a and MAC levels in CSF } \\
\text { correlated with admission, death, and } \\
\text { worse outcome. } \\
\text { 2-(1) CSF WBC count was lower in } \\
\text { C5aR deficient compared to WT mice. } \\
\text { While C5aR deficient mice exhibited } \\
\text { reduced clinical scores, there was no } \\
\text { difference in cerebellar bacterial titers. } \\
\text { 2-(2) Anti-C5 antibody treatment was } \\
\text { protective against pneumococcal } \\
\text { meningitis. }\end{array}$ & $\begin{array}{l}\text { Complement } \mathbf{C 5} \text { activation is } \\
\text { associated with poor outcome } \\
\text { of pneumococcal meningitis. } \\
\text { C5 inhibition is protective } \\
\text { against meningitis. }\end{array}$ & $\begin{array}{l}\text { Woehrl et al., } \\
2011\end{array}$ \\
\hline 4 & $\begin{array}{l}\text { Streptococcus } \\
\text { pneumoniae }\end{array}$ & $\begin{array}{l}\text { (in vivo) Pneumococcal } \\
\text { meningitis model using rats } \\
\text { infected with Streptococcus } \\
\text { pneumoniae. } \\
\text { Rats treated with } \mathbf{C 1} \text { inhibitor } \\
\text { (C1-inh.) intravenously or } \\
\text { intrathecally. }\end{array}$ & $\begin{array}{l}\text { (1) Intrathecal treatment with } \mathbf{C} 1 \text {-inh } \\
\text { reduced clinical symptoms and } \\
\text { inflammatory infiltrate/leukocyte influx. } \\
\text { (2) C1-inh treatment induced } \mathbf{C R} 3 \\
\text { expression in the brain. }\end{array}$ & $\begin{array}{l}\text { (a) Inhibition of classical } \\
\text { complement pathway is } \\
\text { protective against bacterial } \\
\text { meningitis. } \\
\text { (b) } \mathbf{C 1} \text {-inh treatment induced } \\
\text { upregulation of } \mathbf{C R} \mathbf{3} \text {, which } \\
\text { may be protective. }\end{array}$ & $\begin{array}{l}\text { Zwijnenburg } \\
\text { et al., } 2007\end{array}$ \\
\hline 5 & $\begin{array}{l}\text { Neisseria } \\
\text { meningitidis }\end{array}$ & $\begin{array}{l}\text { (in vivo) Human CD46 } \\
\text { transgenic mice vs. WT } \\
\text { infected with } N \text {. meningitidis. } \\
\text { (WT and LPS-deficient) }\end{array}$ & $\begin{array}{l}\text { Human CD46 transgenic mice showed: } \\
\text { (1) delayed bacterial clearance from } \\
\text { blood and increased serum cytokines } \\
\text { (TNF, IL-6, and IL-10). } \\
\text { (2) microglial and astroglial activation in } \\
\text { the brain. } \\
\text { (3) Host immune responses were } \\
\text { absent when LPS-deficient } \\
\text { meningococci were used. }\end{array}$ & $\begin{array}{l}\text { CD46 is crucial in the } \\
\text { pathogenesis of meningitis. }\end{array}$ & $\begin{array}{l}\text { Johansson } \\
\text { et al., } 2005\end{array}$ \\
\hline 6 & $\begin{array}{l}\text { Neisseria } \\
\text { meningitidis }\end{array}$ & $\begin{array}{l}\text { (in vivo) Human CD46 } \\
\text { transgenic mice vs. WT } \\
\text { infected with } N \text {. meningitidis. }\end{array}$ & $\begin{array}{l}\text { (1) N. meningitidis crossed BBB in } \\
\text { CD46 transgenic but not WT mice. } \\
\text { (2) CD46 transgenic mice had } 100 \% \\
\text { mortality, while } 100 \% \text { of WT mice } \\
\text { survived. }\end{array}$ & $\begin{array}{l}\text { Human CD46 facilitates } \\
\text { bacterial translocation across } \\
\text { BBB. }\end{array}$ & $\begin{array}{l}\text { Johansson } \\
\text { et al., } 2003\end{array}$ \\
\hline 7 & $\begin{array}{l}\text { Meningitis-causing } \\
\text { bacteria }\end{array}$ & $\begin{array}{l}\text { (Human) Brain tissue autopsy } \\
\text { from bacterial meningitis } \\
\text { patients }\end{array}$ & $\begin{array}{l}\text { C3aR was upregulated and expressed } \\
\text { by reactive astrocytes, microglia, and } \\
\text { infiltrating macrophages and } \\
\text { neutrophils. }\end{array}$ & $\begin{array}{l}\text { C3aR is upregulated in glial } \\
\text { cells and infiltrating immune } \\
\text { cells in the brain. }\end{array}$ & $\begin{array}{l}\text { Gasque et al., } \\
1998\end{array}$ \\
\hline 8 & $\begin{array}{l}\text { Listeria } \\
\text { monocytogenes }\end{array}$ & $\begin{array}{l}\text { (in vivo) Bacterial meningitis } \\
\text { model, mice infected with } \\
\text { Listeria monocytogenes. }\end{array}$ & $\begin{array}{l}\text { C3 and FB mRNA levels were elevated } \\
\text { in CSF, neurons and Purkinje cells. }\end{array}$ & $\begin{array}{l}\text { Alternative complement } \\
\text { pathway (C3 and } \mathbf{F B}) \text { is } \\
\text { activated in the brain. }\end{array}$ & $\begin{array}{l}\text { Stahel et al., } \\
1997\end{array}$ \\
\hline
\end{tabular}

The relevant complement proteins are highlighted in bold. 
(Liszewski et al., 2000; Lyzogubov et al., 2014). N. meningitidis does not enter the brain in wild-type mice. However, in genetically engineered mice that express human CD46 (human CD46 transgenic), N. meningitidis traversed BBB, leading to significantly higher mortality (Johansson et al., 2003). In addition to delayed bacterial clearance from the circulation, microglial and astroglial activation was observed in the brain of CD46 transgenic mice (Johansson et al., 2005). These data suggest that $N$. meningitidis utilizes CD46 to facilitate its own entry into the CNS.

Systemic infection and sepsis can sensitize the brain to inflammation via complement activation, even without the bacteria entering the CNS. In preterm infants, S. epidermidis triggers cerebral inflammation, white matter injury and impaired neurodevelopment ( $\mathrm{Bi}$ et al., 2015). While Toll-like receptor 2 (TLR2) is thought to be the major contributor to neonatal infection caused by Gram-positive bacteria, the observation that the CSF levels of C1r, C3, and C5 were rapidly increased in S. epidermidis infection-induced sepsis model in pigs (Muk et al., 2019) suggests that systemic infection may cause CNS injury via aberrant activation of the complement cascade. Bacterial lipopolysaccharide-induced long-term depression via microglial CR3 activation offers a specific mechanistic link between neuroinflammation, complement activation, synaptic dysfunction, and memory impairments (Zhang et al., 2014).

While complement protects the host against bacterial infection, excessive complement activation can contribute to CNS injury and long lasting or permanent dysfunction. In addition, several complement components and regulators are exploited by bacteria to facilitate their entry into the CNS.

\section{Viruses}

A large number of brain disease-causing viruses, including herpes viruses (human herpes virus 1 [HSV-1], human herpesvirus 6 [HHV-6], and $\gamma$-herpesviruses), HIV, measles virus, Borna disease virus (BDV), Theiler's murine encephalitis virus (TMEV), Venezuelan equine encephalitis virus (VEEV), West Nile virus (WNV), and Zika virus (ZIKV), interact with the complement system in the CNS (Table 1.2) and this interaction may play a role in neurodegeneration. Latent HSV-1 infection is associated with increased risk for AD (Itzhaki, 2018). HHV-6A and HHV-6B are frequently found in patients with neuroinflammatory diseases including MS (Alvarez-Lafuente et al., 2006) and AD (Readhead et al., 2018). $\gamma$-herpesviruses, including human Epstein-Barr virus (EBV or HHV-4) and Kaposi's sarcoma-associated herpesvirus (KSHV or HHV-8), also establish life-long latency in the host, which is associated with increased risk of diverse neurological conditions, including meningitis, encephalitis, HIV-related CNS lymphoma, and MS (Said et al., 1997; Bossolasco et al., 2006; Serafini et al., 2007). Seropositivity for EBV is associated with clinical AD (Carbone et al., 2014). In HIV patients, KSHV infection can manifest in the CNS (Andrews et al., 2011; Baldini et al., 2013; Tso et al., 2017). In addition, HIV can cause cognitive impairment, so called HIV-associated neurocognitive disorders (HAND, NeuroAIDS). Indeed, while antiretroviral therapy effectively inhibits viral replication and reduces mortality, more than 50\% of HIV-positive individuals suffer from cognitive impairment (Clifford, 2017; Olivier et al., 2018). Even though antiretroviral therapy suppresses viral replication, neurotoxic HIV proteins, such as Tat, continue to be produced in the CNS, leading to persistent inflammation (Liu et al., 2014; Avalos et al., 2017). $\mathrm{WNV}$ is a neuroinvasive pathogen that causes significant neuronal loss, inflammation, and microglial activation (Clarke et al., 2014). WNV targets hippocampal neurons (Armah et al., 2007), and patients recovering from WNV disease often suffer from cognitive impairment (Sejvar et al., 2003; Sadek et al., 2010). ZIKV is the causative agent of Zika fever, congenital infection which leads to severe developmental neurodevelopmental defects, including neonatal microcephaly (Rasmussen et al., 2016; Russo et al., 2017). The fact that ZIKV infection in adults can lead to neurological complications such as acute myelitis, encephalomyelitis, encephalitis, meningoencephalitis, and sensory polyneuropathy (Mécharles et al., 2016; Brito Ferreira et al., 2017), further strengthens the notion that ZIKV is highly neurotropic (Souza et al., 2019). VEEV is endemic to Central and South America and periodically emerges from the enzootic cycle to cause infection in human and equid populations (Weaver and Barrett, 2004), occasionally causing severe encephalomyelitis (Weaver et al., 2004). Measles virus infects over 40 million individuals per year (McChesney and Oldstone, 1989). Acute infection can cause encephalomyelitis, the neurological sequelae of which include subacute sclerosing panencephalitis (SSPE) and measles inclusion body encephalitis (MIBE) (Griffin, 2020).

The complement system provides the first line of defense against viruses, including $\mathrm{HSV}-1$ via the lectin pathway (Bibert et al., 2019), and $\gamma$-herpesvirus, VEEV, and WNV via C3-dependent elimination mechanisms (Kapadia et al., 2002; Mehlhop et al., 2005; Brooke et al., 2012). On the other hand, the virus-induced up-regulation of complement components in the CNS may lead to BBB dysfunction and contribute to tissue damage in infection with HIV and TMEV (Speth et al., 2004; Woollard et al., 2014; Libbey et al., 2017). For example, HIV-Tat protein upregulated C3 expression in human brain microvascular endothelial cells (HBMEC) in vitro (Woollard et al., 2014), C1q is upregulated in the brain of Simian immunodeficiency virus (SIV)-infected rhesus macaques (Speth et al., 2004; Depboylu et al., 2005) and mice after HIV-Tat injection into the cerebral cortex (Hammond et al., 2018), two in vivo models of NeuroAIDS. Increased C1q in the CSF is associated with cognitive impairment in HIV-infected individuals (McGuire et al., 2016). BDV induced local C1q mRNA expression in the hippocampus and cortex (Dietzschold et al., 1995) and ZIKV infection enhanced expression of $\mathrm{Clq}$ and $\mathrm{C} 3$, associated with microglial activation and hippocampal synaptic damage and memory impairment in a murine infection model using ZIKV intracerebroventricular infusion (Figueiredo et al., 2019). In murine model induced by intracranial infection of WNV, C1q protein colocalized with microglia adjacent to WNV-infected neurons, possibly causing synaptic terminal loss (Vasek et al., 2016). These data suggest that local complement activation may induce cognitive impairment via the disruption of neurotransmission. 
TABLE 1.2 | Interactions between complement and viruses in the CNS.

\begin{tabular}{|c|c|c|c|c|c|}
\hline & Pathogen & Study design & Outcomes & Conclusion(s) & References \\
\hline \multicolumn{6}{|c|}{ Borna disease virus (BDV) } \\
\hline 1 & $\begin{array}{l}\text { Borna disease } \\
\text { virus (BDV) }\end{array}$ & $\begin{array}{l}\text { (in vivo) BDV infection model in } \\
\text { rats (intranasal infection) }\end{array}$ & $\begin{array}{l}\text { (1) C1q mRNA was upregulated in the brain of } \\
\text { BDV-infected rats. } \\
\text { (2) C1q positive cells (presumably microglia) were } \\
\text { preferentially localized in the hippocampus and } \\
\text { basolateral cortex. }\end{array}$ & $\begin{array}{l}\text { Local C1q expression is } \\
\text { induced in the brain after BDV } \\
\text { infection. }\end{array}$ & $\begin{array}{l}\text { Dietzschold } \\
\text { et al., } 1995\end{array}$ \\
\hline \multicolumn{6}{|c|}{ Herpes viruses } \\
\hline 1 & HSV-1 & $\begin{array}{l}\text { (1) (Human, clinical case report) } \\
\text { Herpes simplex virus } \\
\text { encephalitis (HSE) in patients. } \\
\text { (2) (in vivo) HSV-1 } \\
\text { infection-induced HSE in } \\
\text { MBL-deficient mice. }\end{array}$ & $\begin{array}{l}\text { (1) HSE patients had } \mathbf{M A S P 2} \text { heterozygous } \\
\text { mutation (G634R and R203W) without defect in } \\
\text { TLR3-interferon signaling pathway. Both } \mathbf{M A S P 2} \\
\text { variants induced functional defects in MASP-2 and } \\
\text { reduced antiviral activity. } \\
\text { (2) MBL deficient mice showed a decreased } \\
\text { survival rate and increased HSV-1 burden in the } \\
\text { brain. }\end{array}$ & $\begin{array}{l}\text { The lectin pathway (MASP-2 } \\
\text { and } \mathbf{M B L} \text { ) is involved in the } \\
\text { anti-HSV activity. Defect in the } \\
\text { lectin pathway can lead to } \\
\text { higher susceptibility to adult } \\
\text { HSE. }\end{array}$ & $\begin{array}{l}\text { Bibert et al., } \\
2019\end{array}$ \\
\hline 2 & $\mathrm{HHV}-6 \mathrm{~A}$ & $\begin{array}{l}\text { (in vitro) HHV-6A infection } \\
\text { model using astroglioblastoma } \\
\text { and neuroblastoma cell lines, T } \\
\text { cell line, peripheral blood } \\
\text { mononuclear cells (PBMC) from } \\
\text { healthy donors, and cord blood } \\
\text { mononuclear cells (CBMC). }\end{array}$ & $\begin{array}{l}\text { (1) C3b induced MSRV-Env expression. } \\
\text { (2) Antibodies recognizing SCR3 and/or SCR4 of } \\
\text { CD46 triggered MSRV transactivation. } \\
\text { (3) Knockdown of CD46-Cyt1 isoform led to loss of } \\
\text { HHV-6A-induced MSRV-Env expression. }\end{array}$ & $\begin{array}{l}\text { The engagement of } \\
\text { CD46-SCR3 and/or } \\
\text { CD46-SCR4, either by HHV-6A } \\
\text { or C3b, induces MSRV-Env. } \\
\text { HHV-6A-induced MSRV-Env } \\
\text { can activate TLR4 signaling. }\end{array}$ & $\begin{array}{l}\text { (Charvet et al., } \\
\text { 2018) }\end{array}$ \\
\hline 3 & HSV-1 & $\begin{array}{l}\text { (in vitro) HSV-1 brain infection } \\
\text { model using human primary } \\
\text { neural cells (neurons + glia). }\end{array}$ & $\begin{array}{l}\text { (1) HSV-1 infection in neural cells caused atrophy } \\
\text { and irregular morphology. } \\
\text { (2) Infection induced the up-regulation of } \\
\text { miRNA-146a and pro-inflammatory mediators, } \\
\text { while reducing FH protein (known as a } \\
\text { miRNA-146a target) levels. } \\
\text { *miRNA-146a: a brain-enriched miRNA }\end{array}$ & $\begin{array}{l}\text { HSV-1 infection in neural cells } \\
\text { lead to the down-regulation of } \\
\text { FH via the induction of } \\
\text { miRNA-146a. }\end{array}$ & (Hill et al., 2009) \\
\hline 4 & HHV-6 & $\begin{array}{l}\text { (in vitro) HHV-6 and measles } \\
\text { virus (MV) infection-induced } \\
\text { fusion model using infected T } \\
\text { cells (HSB-2) and primary } \\
\text { human glia. }\end{array}$ & $\begin{array}{l}\text { (1) Human oligodendrocytes, astrocytes and } \\
\text { microglia express CD46. } \\
\text { (2) CD46 inhibition (anti-CD46 antibody) } \\
\text { suppressed the fusion of HHV-6-infected T cells } \\
\text { with glial targets (oligodendrocytes and astrocytes). }\end{array}$ & $\begin{array}{l}\text { HHV-6 may spread into the } \\
\text { CNS via cell-cell fusion of } \\
\text { infected lymphocytes and glial } \\
\text { cells, which is mediated by } \\
\text { CD46 on the surface of glia. }\end{array}$ & $\begin{array}{l}\text { Cassiani-Ingoni } \\
\text { et al., } 2005\end{array}$ \\
\hline 5 & $\gamma$-herpesviruses & $\begin{array}{l}\text { (in vivo) Murine } \gamma \text {-herpesvirus } \\
68 \text { infection model. } \\
\text { Virus: RCA homolog } \\
\text { (gHB68-RCA) deficient virus vs. } \\
\text { WT. } \\
\text { Host: } \mathbf{C} 3 \text { or FB deficient vs. WT } \\
\text { mice. }\end{array}$ & $\begin{array}{l}\text { (1) gHV68-RCA deficient virus exhibited lower } \\
\text { infection efficiency in the brain and periphery (lung } \\
\text { and spleen) in acute and chronic infection. } \\
\text { (2) } \mathbf{C 3} \text { deficient caused higher susceptibility to viral } \\
\text { latency in the CNS. } \\
\text { (3) Lower infection efficiency of gHV68-RCA } \\
\text { deficient virus compared to WT virus was absent in } \\
\text { C3 deficient mice (but not in FB deficient mice). }\end{array}$ & $\begin{array}{l}\text { (a) } \mathbf{C} 3 \text { prevents viral latency in } \\
\text { the CNS. } \\
\text { (b) Viral RCA protein plays a } \\
\text { key role in viral virulence by } \\
\text { inhibiting } \mathbf{C 3} \text {-dependent host } \\
\text { defense. }\end{array}$ & $\begin{array}{l}\text { Kapadia et al., } \\
2002\end{array}$ \\
\hline
\end{tabular}

RCA: regulators of complement activation

\begin{tabular}{|c|c|c|c|c|}
\hline & Study design & Outcomes & Conclusion & References \\
\hline \multicolumn{5}{|c|}{ HIV } \\
\hline 1 & $\begin{array}{l}\text { (in vivo) HAND model: HIV-Tat protein injection } \\
\text { into the cerebral cortex in WT and C1qa } \\
\text { deficient mice. }\end{array}$ & $\begin{array}{l}\text { (1) C1q and } \mathbf{C} 3 \text { were upregulated around } \\
\text { injection site and corpus callosum in HAND } \\
\text { model (Tat-injected). } \\
\text { (2) lba1+ microglia increase and synaptic loss } \\
\text { were induced in HAND model. } \\
\text { (3) C1q deficient did not prevent Tat-induced } \\
\text { synaptic loss and microgliosis. }\end{array}$ & $\begin{array}{l}\text { (a) Increased } \mathbf{C 1 q} \text { and } \mathbf{C 3} \text {. } \\
\text { (b) Microgliosis and synaptic } \\
\text { loss induced in HAND are } \\
\text { independent of classical } \\
\text { complement cascade (C1q). } \\
\text { (c) The role of } \mathbf{C} 3 \text { is unknown. }\end{array}$ & $\begin{array}{l}\text { Hammond } \\
\text { et al., } 2018\end{array}$ \\
\hline 2 & $\begin{array}{l}\text { (Human) } \\
\text { Specimens: CSF and blood from HIV+ subjects } \\
\text { with and without cognitive dysfunction. } \\
\text { Design: retrospective cross-sectional } \\
\text { Populations: HIV+ youth (18-24 years, n20) } \\
\text { and older adults (40-46 years, n20) with varying } \\
\text { degree of cognitive impairment }\end{array}$ & $\begin{array}{l}\text { (1) CSF C1q correlated with NFL in subjects } \\
\text { without antiretroviral therapy. } \\
\text { (2) A trend towards ( } p=0.052 \text { ) elevation of CSF } \\
\text { C1q expression in subjects with cognitive } \\
\text { impairment compared to those with normal } \\
\text { cognition. }\end{array}$ & $\begin{array}{l}\text { Increased } \mathbf{C 1 q} \text { in CSF, which is } \\
\text { associated with cognitive } \\
\text { impairment. }\end{array}$ & $\begin{array}{l}\text { McGuire et al., } \\
2016\end{array}$ \\
\hline
\end{tabular}


TABLE 1.2 | Continued

\begin{tabular}{|c|c|c|c|c|}
\hline & Study design & Outcomes & Conclusion & References \\
\hline 4 & $\begin{array}{l}\text { (in vivo) Neuro-AIDS model using } \\
\text { SIV-infected rhesus macaques }\end{array}$ & $\begin{array}{l}\text { (1) C1q protein and transcripts colocalized with } \\
\text { microglial/macrophage lineage in SIV-encephalitic brains. All } \\
\text { SIV-positive cells were also C1q-positive. } \\
\text { (2) CNS-permeant antiretroviral agent decreased C1q } \\
\text { synthesis, SIV burden, and inflammation in } \\
\text { AIDS-symptomatic macaques. }\end{array}$ & $\begin{array}{l}\text { Classical complement } \\
\text { pathway activation. }\end{array}$ & $\begin{array}{l}\text { Depboylu et al., } \\
2005\end{array}$ \\
\hline 5 & $\begin{array}{l}\text { (in vivo) Neuro-AIDS model using } \\
\text { SIV-infected rhesus macaques. } \\
\text { Measures: IHC }\end{array}$ & $\begin{array}{l}\text { (1) C1q and } \mathbf{C} 3 \text { levels increased in astrocytes, microglia, } \\
\text { and neurons of SIV-infected macaques compared to } \\
\text { control. } \\
\text { (2) Infiltrating macrophages and multinuclear cells in the } \\
\text { brain also expressed } \mathbf{C 1 q} \text { and } \mathbf{C} 3 \text { in infected animals. } \\
\text { (3) C1q and } \mathbf{C} 3 \text { were deposited on the membrane of } \\
\text { neurons. }\end{array}$ & $\begin{array}{l}\text { Viral infection induced } \\
\text { complement activation (C1q } \\
\text { and } \mathbf{C 3}) \text {, which may cause the } \\
\text { lysis of bystander neurons. }\end{array}$ & Speth et al., 2004 \\
\hline
\end{tabular}

\section{NFL: neurofilament light chain.}

\section{Measles virus (MV)}

1 (in vitro) MV infection-induced fusion model using infected T cells (HSB-2) and primary human glia.

2 (Human) Postmortem subacute sclerosing panencephalitis (SSPE) brain tissue (n4) vs. control with no neurologic disease. Measures: $\mathrm{IHC}$.

3 (in vivo) CNS MV infection model using CD46 transgenic mice*. Intracerebral infection of a vaccine strain of MV.

*Ubiquitously expressing CD46 with either Cyt1 or Cyt2 cytoplasmic tail. (in vivo and in vitro) MV infection model using human CD46 transgenic mice and cells isolated from transgenic mice. mice expressing human CD46 in the CNS (NSE-CD46)

6

(Human) Postmortem brain subacute sclerosing panencephalitis (SSPE) specimens Measures: $I \mathrm{HC}$
1. Human oligodendrocytes, astrocytes and microglia express CD46.

2. CD46 inhibition (anti-CD46) suppressed the fusion of MV glycoprotein-expressing $T$ cells with glial targets (oligodendrocytes and astrocytes).

1. Strong CD46 signal was observed on cerebral endothelium throughout the brain as well as on ependymal cells lining the ventricles and choroid plexus, while subsets of neurons and oligodendrocytes were also weakly CD46 positive.

2. In SSPE brain, cells in MV-infected lesions were negative for CD46.

1. CD46 transgenic mice (both Cyt1 and Cyt2) were highly susceptible to MV infection compared to non-transgenic control.

2. MV replicated in neurons in the brain. MV induced apoptosis in brain regions, which preceded the death of infected mice.

1. CD46 transgenic mice and murine cells are susceptible to MV infection.

2. MV infection in CD46 transgenic mice causes the suppression of cellular and humoral immune responses compared to WT.

3. MV infection causes glial activation and T cell infiltration, leading to CNS disease (e.g., seizures) in CD46 transgenic mice.

(4) MV spread throughout CNS via axonal transport.

1. MV replicates in neurons in the cortex, hippocampus, and thalamus, leading to lethality in CD46 mice.

2. CNS infiltration of T cells, B cells, and macrophages in MV-infected NSE-CD46 mice,

3. $\mathrm{MHCI}$ and II were up-regulated in the CNS, which was associated with astroglial and microglial activation. (4) MV infection induced apoptosis of neurons.

CD46 was down-regulated in heavily infected brain lesions of SSPE, compared to control and SSPE brain regions distant from the lesion.
MV may spread into the CNS via cell-cell fusion of infected lymphocytes and glial cells, which is mediated by CD46 on the surface of glia.

(1) CD46 is present on endothelial, neuronal, and glial cells in the CNS.

(2) MV infection may down-regulate CD46 in SSPE brain.

CD46 transgenic mice developed progressive infectious measles encephalitis similar to brain disorders in immunocompromised patients.

1. Transgenic mice expressing human CD46 (on the surface of

Oldstone et al. neurons, lymphocytes, macrophages, and dendritic cells) are susceptible to MV infection and MV-induced CNS disease.

2. MV spread in the CNS via axonal transport.

CD46 in the CNS plays a crucial role in MV susceptibility and the development of measles encephalitis.

CD46 expression is reduced by MV infection in SSPE lesions.
Cassiani-Ingon et al., 2005

McQuaid and

Cosby, 2002

Evlashev et al., 2000
Manchester et al., 1999
Ogata et al., 1997 
TABLE 1.2 | Continued

\begin{tabular}{|c|c|c|}
\hline & Study design & Outcomes \\
\hline 7 & $\begin{array}{l}\text { (in vivo and in vitro) MV infection } \\
\text { model in transgenic mice } \\
\text { expressing human CD46 in the } \\
\text { CNS (NSE-CD46) and primary } \\
\text { neurons. }\end{array}$ & $\begin{array}{l}\text { 1. MV spread in the brain (hippocampus and cortex) of } \\
\text { NSE-CD46 transgenic mice, but not in WT. } \\
\text { 2. MV spread in CD46 transgenic primary neurons. }\end{array}$ \\
\hline
\end{tabular}

\section{Theiler's murine encephalomyelitis virus (TMEV)}

1 (in vivo) TMEV-induced seizure model in mice (TMEV intracerebral infection).

Measures: FACS. $->$ Gene expression analysis. Populations: R1 (CD45 ${ }^{\text {low/int }}$ CD11 ${ }^{+}$, ramified microglia) and R2 (CD45 ${ }^{\text {high } C D 11 b, ~}$ infiltrating macrophage/activated microglia).

Venezuelan equine encephalitis virus (VEEV)

1 (in vivo) VEEV in infection models in mice (WT vs. C3 deficient)

\section{West Nile virus (WNV)}

1 (in vivo) Murine WNV disease recovery model using intracrania infection with WNV-NS5-E218A strain.

Mouse strains: WT, $\mathbf{C} 3$ deficient and $\mathbf{C 3 a R}$ deficient

2 (in vivo) Murine WNV infection model using $\mathbf{C} 3$ deficient, CR1/CR2 deficient, and WT (subcutaneous injection).
1. R2 population increased from 18 to $72 \mathrm{~h}$ after infection.

Only $\mathrm{R} 1$ was detected in naive.

2. C3, C4b, C3ar1, and C5ar1 mRNAs were significantly upregulated.

3. C3 was detected at significantly higher levels in R2 compared to R1 cells.

(4) Other immune regulators, such as cytokines and $\mathrm{MHC}$ I and II genes, were also upregulated.

(1) VEEV infection via peripheral route caused more severe symptom and enhanced invasion and inflammation in the brain of $\mathbf{C} \mathbf{3}$ deficient mice compared to WT.

(2) Direct inoculation of VEEV into the brain led to identical outcomes irrespective of the presence or absence of $\mathbf{C} 3$.

(1) WNV infection causes synaptic loss in the hippocampal CA3 region.

(2) WNV-recovered mice exhibited cognitive deficits without impairment in motor activity.

(3) C1qa protein colocalized with microglial processes adjacent to neurons. $\mathbf{C} \mathbf{3 d}$ colocalized with synaptic terminals.

(4) $\mathbf{C 3}$ deficient and $\mathbf{C 3 a R}$ deficient mice were protected against WNV-induced synaptic loss.

(1) WNV was detected earlier and in greater levels in the brain and spinal cord of $\mathbf{C} 3$ deficient and $\mathbf{C R 1 / C R 2 ~ d e f i c i e n t ~}$ mice, compared to WT.

(2) High levels of WNV antigen were detected primarily in neurons. In WT mice, WNV positive neurons were detected in the cortex, hippocampus, and brain base. Significantly enhanced and more widespread WNV signals were observed throughout the brain in $\mathbf{C} 3$ deficient compared to WT mice.

(3) The development of WNV-specific antibodies was blunted in $\mathbf{C 3}$ deficient and $\mathbf{C R} \mathbf{1} / \mathbf{C R} \mathbf{2}$ deficient mice. C3 deficient and CR1/CR2 deficient mice had higher mortality after exposure to a low dose WNV. (a) TMEV infection induced upregulation of $\mathbf{C} \mathbf{3}, \mathbf{C} \mathbf{4 b}$,

C3aR, and C5aR in the CNS.

(b) $\mathbf{C} 3$ was highly expressed in infiltrating macrophages/activated microglia.

C3-dependent viral clearance in the periphery is critical for the protection against VEEV-induced encephalitis.

(a) WNV infection caused complement activation (C1q) on microglia and neurons. (b) $\mathbf{C}$ and $\mathbf{C} \mathbf{3} \mathbf{a R}$ signaling mediate hippocampal synaptic terminal loss in WNV-recovering mice.

C3 and CR1/CR2 play a key role in antibody-mediated protection against WNV, thereby reducing the risk of viral dissemination into the brain.
Libbey et al., 2017

References

Rall et al., 1997

Brooke et al. 2012

Vasek et al., 2016

Mehlhop et al., 2005

Complement receptor 1 (CR1): C3b/C4b receptor, CD35.

Complement receptor 2 (CR2): complement C3d receptor, Epstein-Barr virus receptor, CD21.

\section{Zika virus (ZIKV)} Study design

$1 \quad$ (1) (in vivo) ZIKV infection model in mice (intracerebroventricular infusion).

(2) (Human, ex vivo) ZIKV infection in human adult cortical tissue ex vivo.

\section{Outcomes}

(1.1) ZIKV infected mature neurons in the frontal cortex and hippocampus in mice.

(1.2) Infection caused microgliosis, the elevation of TNF-a, and upregulation of complement proteins (C1q and C3).

(1.3) Infection caused hippocampal synaptic damage and memory impairment.

(2) ZIKV infected mature neurons and replicated in adult human brain tissue.

\section{Conclusion}

(a) ZIKV infects neurons in the hippocampus and frontal cortex (b) ZIKV infection causes upregulation of complement proteins ( $\mathbf{C 1 q}$ and $\mathbf{C} \mathbf{3}$ ), which is associated with microglial activation and pro-inflammatory response.

The relevant complement proteins are highlighted in bold.

\section{References}

Figueiredo et al., 2019 
Some viruses increase their virulence by manipulating complement regulatory proteins. HSV-1 infection caused the down-regulation of $\mathrm{FH}$ in human primary neuroglia in vitro (Hill et al., 2009), potentially leading to enhanced activity of the alternative pathway. As suggested by studies using CD46 transgenic mice, CD46 is involved in the dissemination of measles virus into the CNS, increasing the risk of measles encephalitis (Rall et al., 1997; Manchester et al., 1999; Oldstone et al., 1999; Evlashev et al., 2000). In postmortem SSPE brain tissues, strong CD46 signal was observed on cerebral endothelium throughout the brain, as well as ependymal cells lining the ventricles and choroid plexus (McQuaid and Cosby, 2002), while CD46 expression was suppressed by measles virus infection in SSPE lesions (Ogata et al., 1997; McQuaid and Cosby, 2002). In addition, CD46 expression was observed in primary human glial cells (oligodendrocytes, astrocytes, and microglia) and CD46 inhibition by anti-CD46 antibody suppressed the fusion of glia and measles virus-infected T cells in vitro, suggesting that measles virus may spread in the brain parenchyma via binding to CD46 on glia (Cassiani-Ingoni et al., 2005). In HHV-6 infection models in vitro, using neuronal and glial cell lines, CD46 also mediated HHV-6 infection-induced transactivation of Multiple SclerosisAssociated Retrovirus (MSRV) (Charvet et al., 2018). In a murine $\gamma$-herpesviruses infection model, C3 deficiency caused higher susceptibility to viral latency in the CNS (Kapadia et al., 2002). Several $\gamma$-herpesviruses encode homologues of RCAs (Farriesa and Atkinson, 1991), to inhibit complement activation (Fodor et al., 1995; Kapadia et al., 1999, 2002) thereby preventing complement-mediated elimination (Liszewski et al., 1996; Russo et al., 1996; Virgin et al., 1997). Like bacteria, some viruses can utilize and mimic host RCA proteins for their dissemination and entry into the CNS.

Sustained complement activation is associated with neuroinflammation and neurodegeneration in a number of neurological disorders (Eikelenboom et al., 1989; Rogers et al., 1992). Of note, COVID-19 patients reportedly suffer from diverse neurological complications (Stracciari et al., 2021). Although there is no direct evidence thus far to indicate causality between SARS-CoV-2 infection and neuropathology (Maury et al., 2021), future research will show whether there is a causal link between overactivation of complement in response to SARS$\mathrm{CoV}-2$ and neurological symptoms or long-term complications of COVID-19 (Garred et al., 2021).

\section{Fungi}

Fungal infection and dissemination into the brain has been proposed to contribute to the etiology of $\mathrm{AD}$ (Alonso et al., 2014, 2018). Candida is one of the most common commensal fungi, and can cause systemic infections which frequently affect the CNS (Lionakis et al., 2011; Alonso et al., 2014, 2018). Mice with invasive candidiasis exhibit microglial activation and local inflammation (Lionakis et al., 2011). Aspergillus and Cryptococcus are also fungal species that can cause invasive CNS infection, especially in immunocompromised individuals (Panackal and Williamson, 2015). Similarly, cerebral aspergillosis is caused by Aspergillus spp. that mainly affect immunocompromised individuals, such as AIDS patients and those under immunosuppressive treatment regimens (Ruhnke et al., 2007). Cryptococcosis, caused by the encapsulated fungus Cryptococcus neoformans, frequently occurs in AIDS, organ transplant recipients and cancer patients, and is the leading cause of mortality in immunocompromised individuals (Rajasingham et al., 2017). These fungal species can also cause meningoencephalitis (Gottfredsson and Perfect, 2000; Góralska et al., 2018), suggesting that fungal infection-induced local inflammation and meningoencephalitis may lead to long-term sequelae including cognitive dysfunction.

The complement system plays pivotal roles in the susceptibility to fungal CNS infection and infection-induced neuropathology (Table 1.3). A study using murine Candida albican infection models showed that C5 could be a major determinant of CNS infection susceptibility (Tuite et al., 2005). Neutrophils play a major protective role against dissemination of C. neoformans (Lovchik and Lipscomb, 1993; Graybill et al., 1997), and C5aR signaling is required for infection-induced neutrophil recruitment to the brain as suggested by data obtained in a murine infection model using C5 deficiency and inhibitory anti-C5aR antibodies (Sun et al., 2016). C5 and its cleavage product $\mathrm{C} 5 \mathrm{a}$ are required for pulmonary accumulation of neutrophils upon infection and intravascular clearance of C. neoformans (Lovchik and Lipscomb, 1993; Sun et al., 2016), further confirming the crucial roles for C5 and C5a in neutrophilmediated killing of $C$. neoformans. Jointly, these data suggest that complement activation and C5aR signaling are protective against C. neoformans-induced meningoencephalitis. In postmortem brain tissues from subjects with cerebral aspergillosis, C1q, C4, C3, and C5 were up-regulated in the brain, and co-localized with neurons, astrocytes, oligodendrocytes, and infiltrating macrophages (Rambach et al., 2008).

While the specific mechanistic links between fungal infection and dementia remain to be elucidated (Alonso et al., 2014, 2018), complement may be protective against neurodegenerative disorders via limiting fungal invasion into the CNS.

\section{Parasites}

Protozoan parasites including Toxoplasma gondii and Plasmodium spp. are obligate intracellular organisms that can potentially cause dysfunction and parenchymal injury in the brain. While $T$. gondii infects all nucleated cells of warm-blooded vertebrates, erythrocytes are the main target in Plasmodium infection in vertebrates. Host immune responses to these eukaryotes are very complex (Ivanova et al., 2019). The interactions between the complement system and these protozoa, with relevance for brain pathologies and the potential links to dementia, are summarized in Table 1.4.

\section{Plasmodium}

Plasmodium spp. are the agents causing malaria, one of the deadliest infectious diseases worldwide. Cerebral malaria (CM), caused by $P$. falciparum, is the most severe and life-threatening condition characterized by diffuse encephalopathy. CM is frequently accompanied by seizures and coma, and accounts for the majority of childhood deaths from malaria in endemic regions (Schmutzhard and Gerstenbrand, 1984; Idro et al., 2010; 
TABLE 1.3 | Interactions between complement and fungi in the CNS.

\begin{tabular}{|c|c|c|c|c|}
\hline & Study design & Outcomes & Conclusion & References \\
\hline \multicolumn{5}{|c|}{ Aspergillus spp. } \\
\hline 1 & $\begin{array}{l}\text { (Human) Postmortem brain tissue } \\
\text { specimens from subjects with } \\
\text { cerebral aspergillosis (n16): HIV } \\
\text { infection (n10), tumor therapy (n2), } \\
\text { acute myeloid leukemia (n2), } \\
\text { aplastic anemia (n1), organ } \\
\text { transplantation ( } \mathrm{n} 1) \text {. Compared to } \\
\text { non-infected control (n7). }\end{array}$ & $\begin{array}{l}\text { (1) } \mathbf{C 1 q}, \mathbf{C 4}, \mathbf{C} 3 \text {, and } \mathbf{C 5} \text { were upregulated in the from } \\
\text { Aspergillus-infected brain. } \\
\mathbf{C 1 q}, \mathbf{C} 4, \mathbf{C} \text {, and } \mathbf{C 5} \text { were colocalized with neurons, } \\
\text { astrocytes, oligodendrocytes, and infiltrating macrophages. } \\
\text { (2) High complement levels in the surrounding fibrous } \\
\text { layer, but not in the central necrotic area loaded with fungal } \\
\text { hyphae. }\end{array}$ & $\begin{array}{l}\text { Complement synthesis } \\
\text { increased in astrocytes, } \\
\text { neurons, oligodendrocytes, and } \\
\text { infiltrating macrophages in the } \\
\text { surrounding fibrous layer. }\end{array}$ & $\begin{array}{l}\text { Rambach et al., } \\
2008\end{array}$ \\
\hline \multicolumn{5}{|c|}{ Candida spp. } \\
\hline 1 & $\begin{array}{l}\text { (in vivo) Murine model of Candida } \\
\text { albicans infection. } \\
\text { Genetic susceptibility was } \\
\text { assessed by intercrossing two } \\
\text { inbred strains: AJ (C5 deficient) } \\
\text { and C57BL/6J (B6) }\end{array}$ & $\begin{array}{l}\text { (1) Fungal load in the brain, kidney, and heart was } \\
\text { significantly different between the two inbred strains: A J } \\
\text { was more susceptible compared to B6. } \\
\text { (2) C5 was a strong determinant for the brain and kidney } \\
\text { susceptibility to infection. }\end{array}$ & $\begin{array}{l}\text { C5 is a major gene responsible } \\
\text { for genetic susceptibility to } \\
\text { candidiasis. }\end{array}$ & Tuite et al., 2005 \\
\hline \multicolumn{5}{|c|}{ Cryptococcus } \\
\hline 1 & $\begin{array}{l}\text { (in vivo) Cryptococcus neoformans } \\
\text { infection model in mice (WT, C3 } \\
\text { deficient, and } \mathbf{C 5} \text { deficient). }\end{array}$ & $\begin{array}{l}\text { (1) } \mathbf{C} 3 \text { deficiency, } \mathbf{C 5} \text { deficiency, and } \mathbf{C 5 a R} \text { blockade } \\
\text { (specific anti-C5aR mAb) reduced the intravascular } \\
\text { clearance of C. neoformans. } \\
\text { (2) Upon infection, neutrophils recruitment to the lung and } \\
\text { the brain was less efficient in } \mathbf{C} 3 \text { deficient and } \mathbf{C 5} \text { deficient } \\
\text { mice compared to WT. Neutrophil recruitment was also } \\
\text { inhibited in WT mice treated with anti-C5aR. } \\
\text { (3) } \mathbf{C 5 a R} \text { deficient neutrophils failed to be recruited to the } \\
\text { infected lung. } \\
\text { (4) Intravascular clearance of disseminating C. neoformans } \\
\text { is less efficient in the brain compared to the lung. } \\
\text { (5) LPS-treatment significantly enhanced neutrophil } \\
\text { recruitment to the brain and C. neoformans clearance. }\end{array}$ & $\begin{array}{l}\text { (a) Neutrophil recruitment is } \\
\text { essential for intravascular } \\
\text { clearance of } C \text {. neoformans. } \\
\text { (b) C5aR-dependent neutrophil } \\
\text { recruitment is crucial for } \\
\text { intravascular clearance of } \\
\text { C. neoformans. }\end{array}$ & Sun et al., 2016 \\
\hline
\end{tabular}

The relevant complement proteins are highlighted in bold.

Riggle et al., 2020). In addition, more than $10 \%$ of children who survive CM have persistent neurological sequelae, including those affecting cognition and behavior (Frevert and Nacer, 2014). Among the features of CM is the adherence of Plasmodiuminfected red blood cells (iRBCs) to brain vascular endothelium and BBB dysfunction (Yusuf et al., 2017; Pais and PenhaGonçalves, 2019). Several mechanisms were suggested to explain the severe endothelial damage and vascular leakage in CM, and the proposed hypotheses include hemodynamic hypothesis (Van der Heyde et al., 2006; Wassmer and Grau, 2017), inflammation hypothesis (Silamut et al., 1999; Van der Heyde et al., 2006; Wassmer et al., 2006; Dunst et al., 2017), coagulation dysfunction hypothesis (Grau et al., 2003; Francischetti, 2008; Bridges et al., 2010; OSullivan et al., 2016), and innate immune hypothesis (Pais and Penha-Gonçalves, 2019). However, the exact mechanism remains elusive.

There is evidence suggesting that the complement system plays a significant role in CM pathogenesis. In an early study using murine CM model with $P$. berghei ANKA (Finley et al., 1982), T cell-deficient (nu/nu) mice were protected against $\mathrm{CM}$ compared to $\mathrm{nu} /+$ mice, despite comparable parasitemia. The rapid decrease in serum $\mathrm{C} 3$ and concomitant increase in serum immune complexes observed in wildtype mice were absent in nu/nu mice, indicating the interaction between the complement system and cellular immunity in CM (Finley et al., 1982). C1q and C5 protein levels were also significantly higher in the brain of $\mathrm{CM}$ mice compared to non-CM mice, suggesting the activation of the classical pathway (Lackner et al., 2008). The roles for the complement system in CM were further examined using genetically modified mice, including mice deficient in C5 (Patel et al., 2008; Ramos et al., 2011; Buckingham et al., 2014), C5aR (Ramos et al., 2011; Kim et al., 2014; McDonald et al., 2015), C3 (Ramos et al., 2012), C4 (Ramos et al., 2012), FB (Ramos et al., 2012), and C3aR (Ramos et al., 2011). Notably, C5 deficient mice were fully protected from CM and CM-associated seizures (Ramos et al., 2011; Buckingham et al., 2014), while C5aR deficient mice were only moderately protected (Ramos et al., 2011; Kim et al., 2014). Mice lacking FB, C4, or C3aR showed outcomes comparable to wildtype mice (Ramos et al., 2011, 2012). In addition, C9 deposits were observed in the CNS during CM, and C9 inhibition (neutralizing anti-C9 antibody injection) significantly delayed CM development (Ramos et al., 2011). Results from clinical studies also show complement activation during CM. Serum C5a levels were significantly higher in children with CM compared to those without CM (Kim et al., 2014). Postmortem CM frontal lobes exhibited activation of complement, the coagulation cascade, and platelets (Kumar et al., 2018). These data suggest that MAC formation plays a critical role in $\mathrm{CM}$ pathogenesis. In addition, persistent 
TABLE 1.4 | Interactions between complement and parasites in the CNS.

\begin{tabular}{lll}
\hline Study design & Outcomes & Conclusion
\end{tabular}

\section{Plasmodium}

1 (Human) Proteomic analysis on the frontal lobe (autopsy) of subjects with cerebral malaria (CM) caused by Plasmodium falciparum.

(in vivo) Experimental Malaria in Pregnancy (EMIP) model using P. berghei ANKA in mice (WT vs. C5aR deficient). ANKA in mice (WT and C5 deficient).

(1) (in vivo) CM model using P. berghei ANKA in mice (WT, C5aR deficient, and C5L2 deficient). (2) (Human) Plasma from children presenting with $\mathrm{CM}$ or uncomplicated malaria (UM) (case-control) (in vivo) $\mathrm{CM}$ model using $P$. berghei ANKA in mice (C57BL/6 WT, C4 deficient, $\mathbf{F B}$ deficient, and $\mathbf{C 3}$ deficient). $P$. berghei ANKA.

Mouse strains: WT, $\mathbf{C 5}$ deficient, C5aR deficient, and C3aR deficient.

(in vivo) $\mathrm{CM}$ model using $P$. berghei ANKA in mice of different genetic backgrounds.

C5-deficient: A/J, C57BL/6 with C5-defective allele from $\mathrm{A} / \mathrm{J}$, and C5-deficient B10.D2. C5-sufficient: C57BL/6, A/J with C5-sufficient allele from C57BL/6, and C5-deficient B10.D2. (in vivo) $\mathrm{CM}$ model using $P$. berghei ANKA in mice.

(in vivo) $\mathrm{CM}$ model using $P$. berghei ANKA in mice (BALB/c; nu/nu and $\mathrm{nu} /+$ ) (in vivo)
(1) Proteins associated with innate immune response, complement system (C1qb), coagulation, the platelet activation, are elevated in $\mathrm{CM}$.

(2) Proteins associated with myelination, oxidative phosphorylation, ROS regulation, sodium and calcium ion transport are depleted in CM.

(1) In utero exposure to EMIP induced persistent neurocognitive deficit and affective disorders in the offspring.

(2) In utero EMIP-induced cognitive deficit in offspring was rescued by genetic or pharmacological disruption of C5aR signaling.

(3) In utero EMIP-induced reduction in neurotransmitter levels (dopamine, 5- HT, and norepinephrine) was observed only in WT (not in C5aR deficient) offspring.

C5 deficient mice were protected against infection-induced seizures and high spike frequency.

(1) In experimental CM model, C5aR deficient mice (but not C5L2 deficient) showed (moderately) improved survival that was associated with reduced levels of proinflammatory cytokines and chemokine (TNF, IFN-g, and CCL2), as well as preserved endothelial integrity, compared to WT mice. (2) In human subjects, serum C5a levels were significantly higher in CM children compared to UM.

(1) $\mathbf{C 4}$ deficient and $\mathbf{F B}$ deficient mice were fully susceptible to CM.

(2) $\mathbf{C 3}$ deficient mice were partially resistant to $\mathrm{CM}$.

(3) Terminal activation (C5 cleavage) occurred in $\mathbf{C 3}$ deficient mice during $\mathrm{CM}$.

(1) $\mathbf{C 5}$ deficient mice were resistant to cerebral malaria, whereas $\mathbf{C 5 a R}$ deficient and $\mathbf{C} 3 \mathbf{a R}$ deficient mice were susceptible.

(2) $\mathbf{C 9}$ deposition was detected throughout the cortex of infected mice. $\mathbf{C 9}$ deposits frequently colocalized with blood vessels, while some were detected in the parenchyma.

(3) anti-C9 antibody treatment significantly delayed the progress of cerebral malaria.

(1) $\mathrm{CM}$ was associated with the presence of $\mathbf{C 5}$ gene. C5-sufficient mice were susceptible while and C5-deficient mice were CM resistant.

(2) C5a and C5aR blockade rescued susceptible mice from $\mathrm{CM}$.

Increased $\mathbf{C 1 q}$ and $\mathbf{C 5}$ proteins in the brain of cerebral malaria. C1q and $\mathbf{C 5}$ levels correlated with clinical severity.

(1) Compared to nu/t, nu/nu mice were protected against $\mathrm{CM}$ despite higher parasitemia.

(2) Early rapid decrease in serum $\mathbf{C} 3$ and increase in serum immune complex levels were observed in nu/+ mice, but not in nu/nu.

Innate immune responses (including the complement system) and associated demyelination may contribute to the severity of $\mathrm{CM}$.

In utero exposure to MIP induces cognitive deficit in offspring via maternal C5aR signaling.

C5 plays a role in malaria-induced seizures.

Buckingham et al., 2014

Dysregulated C5aR signaling Kim et al., 2014 contributes to the pathogenesis of $\mathrm{CM}$.

Terminal pathway activation during $\mathrm{CM}$ occurs independently of the three upstream pathways, suggesting the crosstalk between coagulation cascade and complement cascade.

Protection of $\mathbf{C 5}$ deficient mice against cerebral malaria is mediated through the inhibition of MAC formation, not through C5a-induced inflammation.

C5 and C5a are responsible for $\mathrm{CM}$ pathogenesis.

C1q and C5 are locally upregulated in the brain in cerebral malaria.

$T$ cell-deficiency is protective against $\mathrm{CM}$, which was accompanied by reduced complement activation.

Kumar et al., 2018

McDonald et al., 2015

Ramos et al., 2012

Ramos et al., 2011

Patel et al., 2008

Lackner et al., 2008

Finley et al., 1982 
TABLE 1.4 | Continued

\begin{tabular}{|c|c|c|c|c|}
\hline & Study design & Outcomes & Conclusion & References \\
\hline \multicolumn{5}{|c|}{ Toxoplasma gondii } \\
\hline & Study design & Outcomes & Conclusion & References \\
\hline 1 & $\begin{array}{l}\text { (in vivo and in vitro) Toxoplasma } \\
\text { infection model: Type II T. gondii } \\
\text { (Fukaya) in mice (in vivo); Type ॥ } \\
\text { T. gondii (PTG) in murine primary } \\
\text { glia (in vitro) }\end{array}$ & $\begin{array}{l}\text { (1) mRNA levels of } \mathbf{C 1 q a}, \mathbf{C 3}, \mathbf{F B}, \mathbf{F P}, \mathbf{C} 3 \mathbf{a R} \text {, and } \mathbf{C 5 a R} \\
\text { were persistently up-regulated in the infected brain. } \\
\text { (2) } \mathbf{C 5 a} \text { protein was up-regulated in the infected brain. } \\
\text { (3) Toxoplasma infection in glial cells induced the } \\
\text { up-regulation of mRNA for } \mathbf{C 1 q a}, \mathbf{F B}, \mathbf{F P} \text {, and } \mathbf{C 5 a R} \text { in a } \\
\text { microglia-dependent manner. }\end{array}$ & $\begin{array}{l}\text { Toxoplasma infection induced } \\
\text { the expression of the alternative } \\
\text { pathway components (FB and } \\
\text { FP) and anaphylatoxin } \\
\text { receptors (C3aR and } \mathbf{C 5 a R ) ,} \\
\text { which was partly mediated by } \\
\text { microglia. }\end{array}$ & $\begin{array}{l}\text { Shinjyo et al., } \\
2021\end{array}$ \\
\hline 2 & $\begin{array}{l}\text { (in vivo) Chronic Toxoplasma } \\
\text { infection model: Type II T. gondii } \\
\text { (Prugniaud) in mice (Kumming). } \\
\text { Measures: proteomics using brain } \\
\text { tissue samples. }\end{array}$ & $\begin{array}{l}\text { Complement (C3, C4b, and } \mathbf{C 1 q a} \text { ) and coagulation (e.g., } \\
\text { plasminogen) pathways were highly upregulated in the brain } \\
\text { of infected mice. Tight junction pathway was disordered. }\end{array}$ & $\begin{array}{l}\text { In Toxoplasma-infected brain, } \\
\text { complement components (C3, } \\
\mathbf{C 4 b} \text {, and } \mathbf{C 1 q )} \text { were } \\
\text { upregulated possibly causing } \\
\text { the disruption of tight junctions. }\end{array}$ & $\begin{array}{l}\text { Huang et al., } \\
2019\end{array}$ \\
\hline 3 & $\begin{array}{l}\text { (in vivo) Persistent infection model: } \\
\text { Type I T. gondii (GT1) in mice } \\
\text { (5 months post infection) }\end{array}$ & $\begin{array}{l}\text { (1) Complement } \mathbf{C 1 q}, \mathbf{C 1 r}, \mathbf{C} \mathbf{3} \text {, and } \mathbf{C} 4 \text { levels were } \\
\text { elevated in the brain with high Toxoplasma cyst burden. } \\
\text { (2) Complement proteins were deposited on the surface } \\
\text { of degenerating neurons. }\end{array}$ & $\begin{array}{l}\text { T. gondii cyst burden is } \\
\text { associated with up-regulation } \\
\text { of complement components } \\
(\mathbf{C} \mathbf{1 q}, \mathbf{C 1 r}, \mathbf{C} \mathbf{3} \text {, and } \mathbf{C} \mathbf{4}) \text {, which } \\
\text { leads to complement } \\
\text { deposition on the surface of } \\
\text { degenerating neurons. }\end{array}$ & Li et al., 2019 \\
\hline 4 & $\begin{array}{l}\text { (in vivo) Chronic Toxoplasma } \\
\text { infection model in mice, using type I } \\
\text { (GT1, virulent) and type II (ME49, } \\
\text { avirulent) strains. }\end{array}$ & $\begin{array}{l}\text { (1) C1q mRNA and protein levels increased after infection. } \\
\text { C1q levels correlated with Toxoplasma cyst burden. } \\
\text { (2) C1q expression was predominantly cytoplasmic, which } \\
\text { was in the cells adjacent to GFAP positive astrocytes, near } \\
\text { breached cyst barriers. } \\
\text { (3) C1q colocalized with Toxoplasma cysts in the brain. }\end{array}$ & $\begin{array}{l}\text { Toxoplasma infection causes } \\
\text { upregulation of } \mathbf{C 1 q} \text { in the } \\
\text { brain, particularly near parasite } \\
\text { cysts and punctate synaptic } \\
\text { patterns. }\end{array}$ & Xiao et al., 2016 \\
\hline
\end{tabular}

The relevant complement proteins are highlighted in bold.

cognitive deficits caused in the offspring by in utero exposure to malaria were dependent on maternal $\mathrm{C} 5 \mathrm{a}-\mathrm{C} 5 \mathrm{aR}$ signaling (McDonald et al., 2015). These findings point to the role of $\mathrm{C} 5 \mathrm{a}$ in the initiation of neuroinflammation together with the dysregulation of angiogenesis and synaptogenesis $(\mathrm{McD}$ onald et al., 2013). Surprisingly, the formation of conventional C5 convertase via $\mathrm{C} 3$ activation was not required for $\mathrm{CM}$ progression (Ramos et al., 2012), which suggests that C5 was activated by coagulation factors or other non-complement proteases (Ramos et al., 2012; Figure 2). These observations support the role for the complement system as a link between immune responses and dysregulated coagulation during CM.

The interactions between Plasmodium and the complement system are possibly even more intricate (Schmidt et al., 2015; Kennedy et al., 2016, 2017; Rosa et al., 2016). Blood stage P. falciparum (free merozoites as well as intraerythrocytic schizonts) evades complement-mediated destruction by recruiting $\mathrm{FH}$, a major negative regulator of complement activation, on the cell surface (Kennedy et al., 2016; Rosa et al., 2016). As mentioned above, several other pathogens, including Neisseria meningitidis (Granoff et al., 2009; Schneider et al., 2009) and Borrelia burgdorferi (Kraiczy et al., 2001), use FH for the same purpose, suggesting that it is an evolutionarily conserved strategy to circumvent complement-mediated elimination. Plasmodium utilizes another complement regulatory protein CR1 as a receptor for red blood cell invasion (Tham et al., 2010; Spadafora et al., 2010). In addition, mobilization of CR1 on the surface of Plasmodium-infected red blood cells is required for rosetting (Rowe et al., 1997), a process implicated in vascular obstruction during severe malaria (Carlson, 1993). CR1 polymorphisms could explain the association between altered efficiency of rosetting and malaria severity (Cockburn et al., 2004; Schmidt et al., 2015).

In conclusion, overactivation of complement cascade triggered by the parasite conceivably contributes to $\mathrm{CM}$ pathogenesis, and the inhibition of the complement cascade at the level or downstream of C5 activation, and/or the inhibition of $\mathrm{CR} 1$ could be a beneficial treatment strategy for CM.

\section{Toxoplasma gondii}

Toxoplasma gondii infects approximately one-third of the world population. It is an opportunistic infection that in individuals with immunodeficiency can cause severe diseases, including Toxoplasma encephalitis (Marra, 2018). Infection during pregnancy can lead to congenital toxoplasmosis, the severity of which depends on the stage of pregnancy (Bigna et al., 2020). While Toxoplasma rarely causes symptoms in healthy individuals with effective immunity, it can establish latent infection in the brain and other tissues (Pittman and Knoll, 2015). It is also notable that the virulence can vary depending on Toxoplasma genotype (Howe and Sibley, 1995; Behnke et al., 2011; Pomares et al., 2018; Taniguchi et al., 2018). Once disseminated into the brain, the parasite transforms into bradyzoite form (cyst) and establishes a life-long infection in neurons and glia (Ólafsson and Barragan, 2020). The presence of Toxoplasma cysts in the CNS has been linked to various 

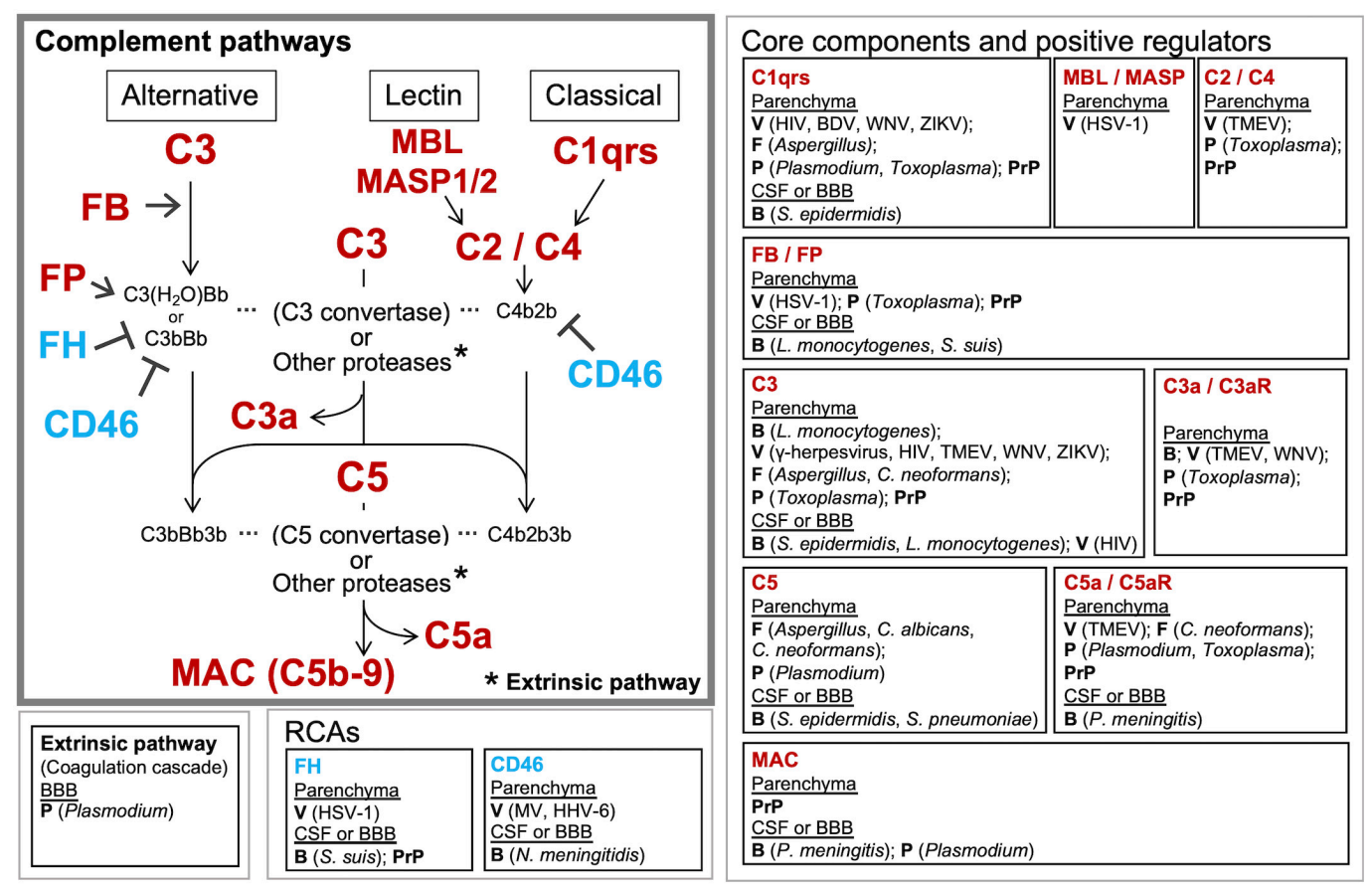

FIGURE 2 | Known and potential interactions between complement proteins and infectious agents. Infectious agents can modulate the expression or activity of complement proteins and receptors in the brain parenchyma, CSF, and BBB. Highlighted are the core complement components/positive regulators (red) and negative regulators (RCAs) (blue), which are potentially affected by infectious agents. Infection-induced activation of the coagulation cascade can also lead to C3 and C5 cleavage via the extrinsic pathway. Pathogens known to interact with the respective complement proteins are presented in the boxes to the right or below the pathway diagram. B, bacteria; V, viruses; F, fungi; P, parasites; PrP, prion proteins.

neuropsychiatric disorders, such as schizophrenia (Elsheikha et al., 2016; Del Grande et al., 2017; Fuglewicz et al., 2017; Fond et al., 2018; Stepanova et al., 2019; Tyebji et al., 2019a,b), possibly via the direct modulation of dopaminergic/serotonergic signaling as well as neuroinflammation (Henriquez et al., 2009; Mahmoud et al., 2017). T cells and type II interferon (IFN- $\gamma$ )dependent immune responses are an essential part of the host defense against Toxoplasma infection (Sasai et al., 2018). Type I interferons (IFNs) also play an important regulatory role in the innate immune response during protozoan infection, including toxoplasmosis (Silva-Barrios and Stäger, 2017).

Toxoplasma is classified into three groups: virulent type I, which causes acute infection, and avirulent type II and type III, which are responsible for chronic infection. Several studies have suggested the involvement of the complement system during acute Toxoplasma (type I) infection. Toxoplasma lytic activity of human sera was dependent on classical pathway components $(\mathrm{C} 1 \mathrm{q}, \mathrm{C} 2, \mathrm{C} 4, \mathrm{C} 5, \mathrm{C} 6, \mathrm{C} 7$, and $\mathrm{C} 8$ ) in a study using a virulent Toxoplasma strain in vitro (Schreiber and Feldman, 1980). Animal sera (pig, rabbit, and dog), with the exception of cat serum, effectively killed Toxoplasma tachyzoites of a virulent strain via $\mathrm{C} 1 \mathrm{q}$ and natural IgM-dependent complement activation (Kaneko et al., 2004). Toxoplasma tachyzoites of the same strain were resistant to complement-mediated lysis via the formation of $\mathrm{iC} 3 \mathrm{~b}$, the inactive form of $\mathrm{C} 3 \mathrm{~b}$ (Fuhrman and Joiner, 1989). Toxoplasma tachyzoites of both virulent and avirulent strains mobilized complement regulatory proteins $(\mathrm{FH}$ and $\mathrm{C} 4 \mathrm{BP}$ ) on their surface to evade complement-mediated parasite killing in vitro, whereas C3 deficient mice suffered higher parasite burden in the brain and other organs in vivo, suggesting complex host-parasite interactions (Sikorski et al., 2020). Of note, C5 deficiency rendered either protection or enhanced mortality depending on the genetic background of the murine host (Araujo et al., 1975). These data suggest that, while the complement system plays a pivotal role in the protection against acute Toxoplasma infection, the parasite has evolved strategies to manipulate the complement system to survive and propagate in the host.

The interaction between Toxoplasma and the complement system in the brain has recently been elucidated. In murine Toxoplasma infection models, cerebral C1q is upregulated during chronic infection with virulent and avirulent strains (Xiao et al., 2016), and persistent infection with a virulent Toxoplasma strain led to the upregulation of $\mathrm{C} 1 \mathrm{q}, \mathrm{C} 1 \mathrm{r}, \mathrm{C} 3$, and C4 mRNA levels and deposition of complement component proteins ( $\mathrm{C} 1 \mathrm{q}$ and $\mathrm{C} 3$ ) in the brain. These changes were associated with neurodegeneration (Li et al., 2019). An avirulent Toxoplasma strain also caused upregulation of complement proteins, including $\mathrm{C} 3, \mathrm{C} 4 \mathrm{~b}$, and C1q, in the mouse brain (Huang et al., 2019). Furthermore, mRNAs for FB and FP, C3aR, and $\mathrm{C} 5 \mathrm{aR}$ were up-regulated in the brain of mice chronically infected with an avirulent Toxoplasma strain (Shinjyo et al., 2021), suggesting that the alternative pathway is activated in the brain during chronic infection. The Toxoplasma infection-induced up-regulation of FB, FP, and C5aR 
mRNAs occurred in primary murine glial cells in vitro in a microglia-dependent manner (Shinjyo et al., 2021). These data suggest that, while complement-dependent clearance is essential in the initial, peripheral phase of infection, chronic Toxoplasma infection can cause persistent complement activation in the CNS.

\section{Prion Proteins}

Transmissible spongiform encephalopathies (TSEs, prion diseases) are fatal neurodegenerative diseases, which include bovine spongiform encephalopathy (BSE) in cattle, scrapie in sheep and goat, Creutzfeldt-Jakob disease (CJD), fatal familial insomnia, and Gerstmann-Sträussler-Scheinker syndrome in humans (Prusiner et al., 1998; Prusiner, 1998). Most neurodegenerative diseases, including prion diseases and $\mathrm{AD}$, share two common features: the accumulation and selfpropagation of misfolded proteins (Gomez-Gutierrez and Morales, 2020). TSE-causing infectious prion proteins $\left(\mathrm{PrP}^{\mathrm{Sc}}\right)$ transmit the disease-associated conformation to normal prion proteins $\left(\mathrm{PrP}^{\mathrm{C}}\right)$, leading to further propagation of $\operatorname{PrP}^{\mathrm{Sc}}$. Following peripheral exposure and prior to neuroinvasion, $\mathrm{PrP}^{\mathrm{Sc}}$ accumulates in lymphoid tissues, including lymph nodes and Peyer's patches. Early $\operatorname{PrP}^{\mathrm{Sc}}$ accumulation occurs within the germinal center on follicular dendritic cells (FDCs) (Brown et al., 1999) as well as within tingible body macrophages (McGovern and Jeffrey, 2007). From the lymphoid tissues, transmission to the CNS occurs via the peripheral nervous system (Glatzel et al., 2001). The central event in prion disease progression is the accumulation of $\mathrm{PrP}^{\mathrm{Sc}}$ in the CNS accompanied by neuronal loss and spongiform neuropils, suggesting aggressive destruction of neural networks (Budka, 2000).

The involvement of the complement system in prion-induced neuropathology has been observed in different types of prion diseases (Bonifati and Kishore, 2007; Table 1.5). In scrapieinfected rodents, total complement activity in the brain was significantly increased at the terminal stage (Lv et al., 2014). In addition, C1q upregulation (Dandoy-Dron et al., 1998, 2000; Carroll et al., 2018), C3 upregulation and colocalization with neurons, and MAC deposition on neurons were observed in infected human brain (Kovacs et al., 2004) as well as in scrapie model in mice ( $\mathrm{Lv}$ et al., 2014), suggesting the activation of the classical and terminal pathways. C1q also colocalized with infected neurons in vitro, and throughout the brain $\mathrm{C1q}$ distribution overlapped with $\operatorname{PrP}$ (Hasebe et al., 2012). In addition, FB and FP levels significantly increased in the brain of scrapie-infected mice, while FB and C3 colocalized with neurons and activated microglia (Chen et al., 2020), suggesting the activation of the alternative pathway and microglia. Notably, mice deficient in $\mathrm{C} 1 \mathrm{q}$ or $\mathrm{FB} / \mathrm{C} 2$ were protected against encephalopathy after intraperitoneal prion exposure, but C3 deficiency was not protective (Klein et al., 2001). Interestingly, reactive astrocytes in prion diseases are characterized by $\mathrm{C} 3$ up-regulation and mixed A1/A2 phenotype (Hartmann et al., 2019) distinct from neurotoxic astrocytes observed in other neurodegenerative diseases (Kwon and Koh, 2020). The abolishment of C3-positive astrocytes led to prion disease acceleration (Hartmann et al., 2019). These data suggest that C3 plays multiple roles in prion disease progression, depending on the context. In contrast, complement hemolytic activity was significantly lower in the CSF of CJD patients, particularly in genetic CJD cases (Chen et al., 2016). In addition, the protein levels of some complement components, including C3, C4, and C9, decreased in the CSF of sporadic CJD (sCJD) patients compared to non-CJD group (Chen et al., 2016). While the explanation conceivably lies in the increased consumption of complement in the brain parenchyma, the neuropathologic implications of these findings are currently elusive.

Given that $\mathrm{FH}$ deficiency was protective against $\operatorname{PrP}$ propagation (Kane et al., 2017), prion proteins may escape complement-mediated clearance by manipulating FH-dependent complement inhibition, possibly via direct interaction between $\mathrm{PrP}^{\mathrm{Sc}}$ and FH (Kane et al., 2017). Thus, RCAs seem important target molecules exploited by infectious agents, including prion proteins, to evade innate immunity and propagate throughout the body including the CNS.

\section{Complement: A Double Edge Sword in the Infected Brain}

The consequences of local complement activation by infectious agents for brain tissue integrity and function are highly context dependent. Complement has a role in the regulation of normal neuronal functioning and homeostasis. It may be neuroprotective and play a critical role in the elimination of various pathogens, but can also be a major mediator of neurodegeneration and tissue damage. The complement system can also be hijacked by some pathogens and play a complicit role in their dissemination. Figure 2 illustrates the potential interactions between the complement system and infectious agents, and Table 2 summarizes the responses of selected complement proteins to the individual pathogens, including up- or down-regulation, deposition, and the impact of genetic polymorphism or genetic manipulations.

In the CNS, C1q plays potentially harmful roles in bacterial (S. pneumoniae-induced bacterial meningitis) (Zwijnenburg et al., 2007), viral (HIV-associated cognitive impairment) (McGuire et al., 2016), parasite (Plasmodium, CM) (Lackner et al., 2008), and prion (Klein et al., 2001) infections, while it may be protective during the initial phase of prion disease (Flores-Langarica et al., 2009). Jointly these findings indicate the deleterious consequences of overactivation of the classical pathway. The lectin pathway is protective against herpes simplex virus encephalitis by inhibiting viral dissemination into the CNS (Bibert et al., 2019). While C3-mediated pathogen clearance is beneficial in the periphery (Mehlhop et al., 2005; Brooke et al., 2012; Sun et al., 2016), C3d deposition on synaptic terminals may facilitate synaptic loss in WNV infection (Vasek et al., 2016). Likewise, the net outcome of downstream complement activation seems to be context-dependent. C5 is important for fungal clearance in the vasculature (Sun et al., 2016) and inhibits fungal dissemination into the CNS (Tuite et al., 2005). In contrast, in the Plasmodium infection, C5 deficiency is protective against CM (Patel et al., 2008; Ramos et al., 2011; Buckingham et al., 2014). Inhibition of MAC formation was also protective against 
TABLE 1.5 | Interactions between complement and prion proteins in the CNS.

\begin{tabular}{|c|c|c|c|c|c|}
\hline & $\begin{array}{l}\text { Pathogen } \\
\text { (disease) }\end{array}$ & Study design & Outcomes & Conclusion & References \\
\hline 1 & $\begin{array}{l}\text { Scrapie (Prion } \\
\text { disease) }\end{array}$ & $\begin{array}{l}\text { (in vivo) Prion disease } \\
\text { model: scrapie-infected } \\
\text { mice }\end{array}$ & $\begin{array}{l}\text { (1) FB and FP (properdin) levels significantly } \\
\text { increased in the brain of scrapie-infected } \\
\text { mice. } \\
\text { (2) FB and } \mathbf{C} 3 \text { colocalization was observed } \\
\text { with neurons and activated microglia, but not } \\
\text { with astrocytes. }\end{array}$ & $\begin{array}{l}\text { The alternative pathway is } \\
\text { activated and plays a role in } \\
\text { triggering the complement } \\
\text { cascade in the brain during } \\
\text { prion infection-induced } \\
\text { neuropathogenesis. }\end{array}$ & Chen et al., 2020 \\
\hline 4 & $\begin{array}{l}\text { Scrapie (Prion } \\
\text { disease) }\end{array}$ & $\begin{array}{l}\text { (in vivo) FH deficient } \\
\text { mouse prion disease } \\
\text { model (scrapie) using } \\
\text { transgenic mice } \\
\text { expressing zero } \\
\text { (FH-/-), one (FH+/-), } \\
\text { or two (FH+/+) allelic } \\
\text { copies of } \mathbf{C f h} \text {. }\end{array}$ & $\begin{array}{l}\text { (1) Brain PrP loads correlated with } \mathbf{C} \boldsymbol{h} \\
\text { expression. } \\
\text { (2) Splenic propagation and clinical } \\
\text { manifestation were delayed by FH deficiency. } \\
\text { (3) FH directly interacts with PrPSc. }\end{array}$ & $\begin{array}{l}\text { (a) } \mathbf{F H} \text { enhances } \\
\text { scrapie-induced brain prion } \\
\text { load. } \\
\text { (b) } \mathbf{F H} \text { directly binds prions. }\end{array}$ & Kane et al., 2017 \\
\hline 6 & $\begin{array}{l}\text { Scrapie (prion } \\
\text { disease) }\end{array}$ & $\begin{array}{l}\text { (in vivo) Prion disease } \\
\text { model (scrapie) in mice } \\
\text { and hamster: } \\
\text { 139A-infected mice } \\
\text { and } 263 \mathrm{~K} \text {-infected } \\
\text { hamster }\end{array}$ & $\begin{array}{l}\text { (1) Total complement activity (CH50) was } \\
\text { higher in the brain of scrapie-infected rodents. } \\
\text { (2) C1q was upregulated in the brain of } \\
\text { scrapie-infected rodents. } \\
\text { (3) Stronger } \mathbf{C} 3 \text { signals in scrapie-infected } \\
\text { brain. } \mathbf{C} 3 \text { colocalized with astrocytes, } \\
\text { microglia, and neurons. } \\
\text { (4) MAC was deposited in the infected brain } \\
\text { and colocalized with neurons. }\end{array}$ & $\begin{array}{l}\text { The activation of the } \\
\text { complement system may be a } \\
\text { hallmark during prion infection. }\end{array}$ & Lv et al., 2014 \\
\hline 7 & $\begin{array}{l}\text { Scrapie (prion } \\
\text { disease) }\end{array}$ & $\begin{array}{l}\text { (in vivo and in vitro) } \\
\text { Scrapie (Chandler and } \\
\text { 22L) infection model: } \\
\text { mice and N2a cells. }\end{array}$ & $\begin{array}{l}\text { (1) C1q colocalized with PrP in } \\
\text { Chandler-infected N2a cells, while C3 } \\
\text { colocalized with PrP in 22L-infected N2a } \\
\text { cells. } \\
\text { (2) } \mathbf{C 1 q} \text { colocalized with PrP throughout the } \\
\text { brain and mild } \mathbf{C 3} \text { deposition was detected in } \\
\text { the cerebral cortex, septum, thalamus, } \\
\text { midbrain, and pons in Chandler-infected } \\
\text { brain. } \mathbf{C 1 q} \text { was absent in the dorsal part of } \\
\text { thalamus and } \mathbf{C} 3 \text { was more pronounced in } \\
\text { the thalamus compared to Chandler-infected } \\
\text { brain. }\end{array}$ & $\begin{array}{l}\text { Prion-induced complement } \\
\text { activation is PrP strain } \\
\text { dependent. }\end{array}$ & $\begin{array}{l}\text { Hasebe et al., } \\
2012\end{array}$ \\
\hline
\end{tabular}


TABLE 2 | The functions of specific complement proteins and in CNS infection.

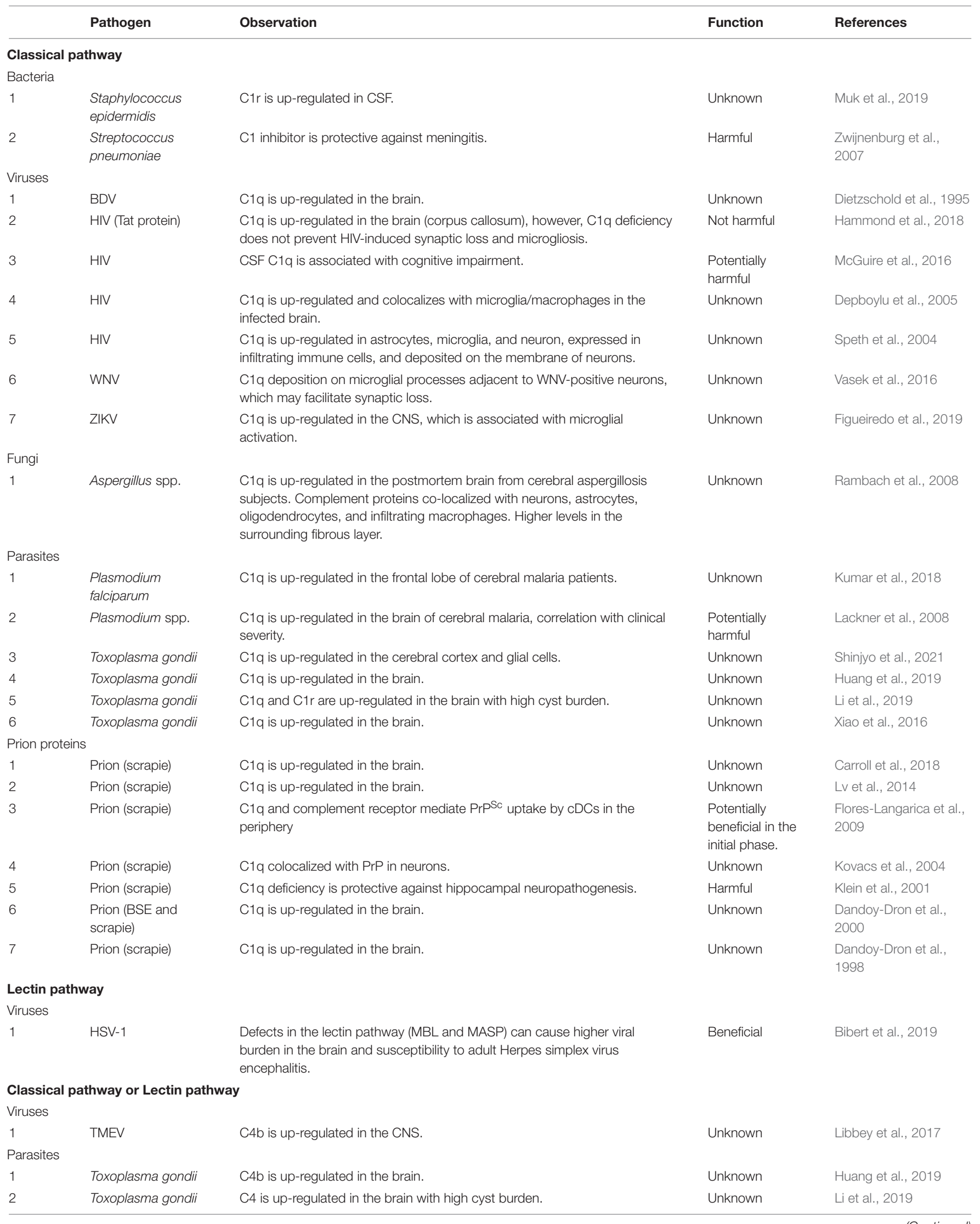


TABLE 2 | Continued

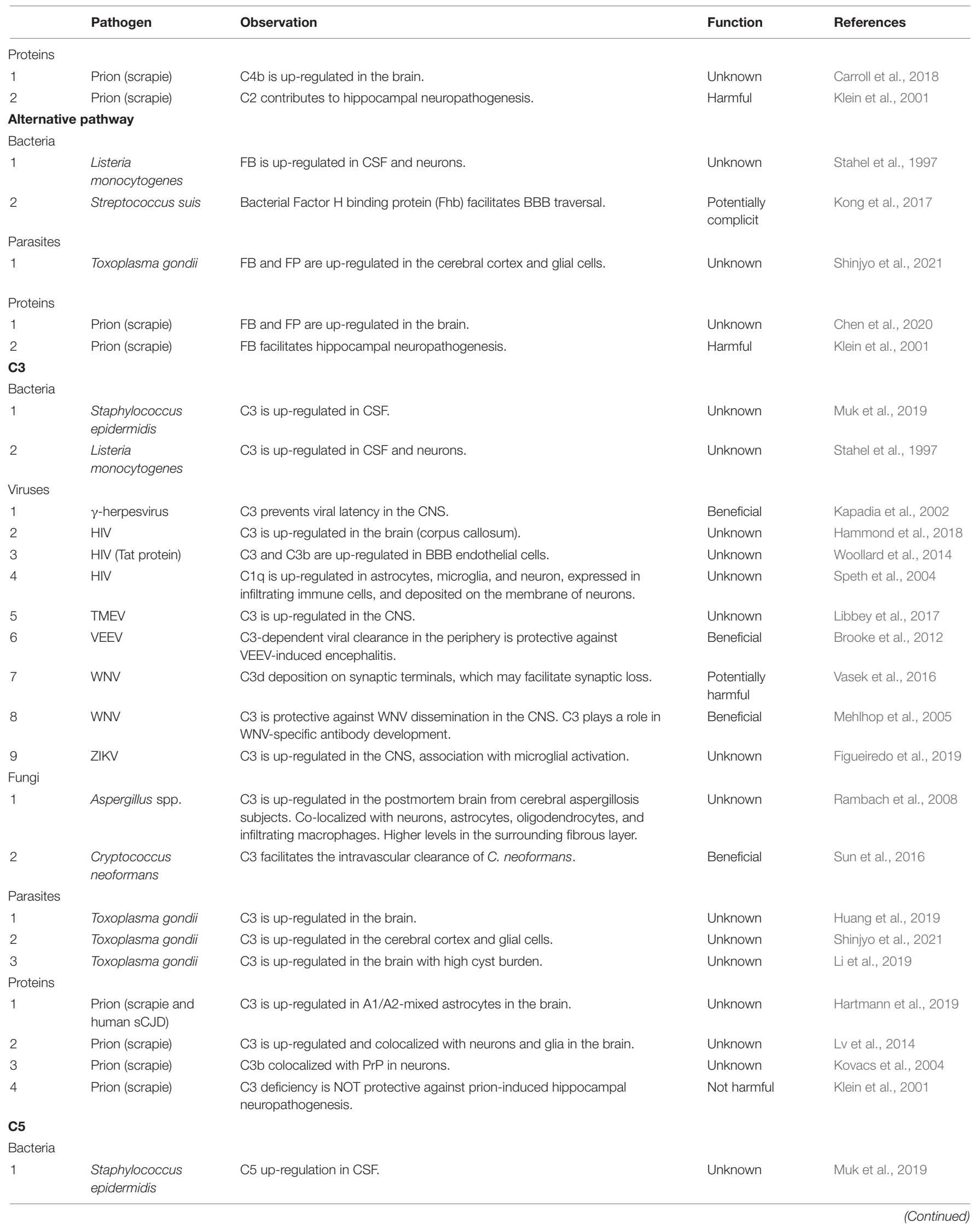


TABLE 2 | Continued

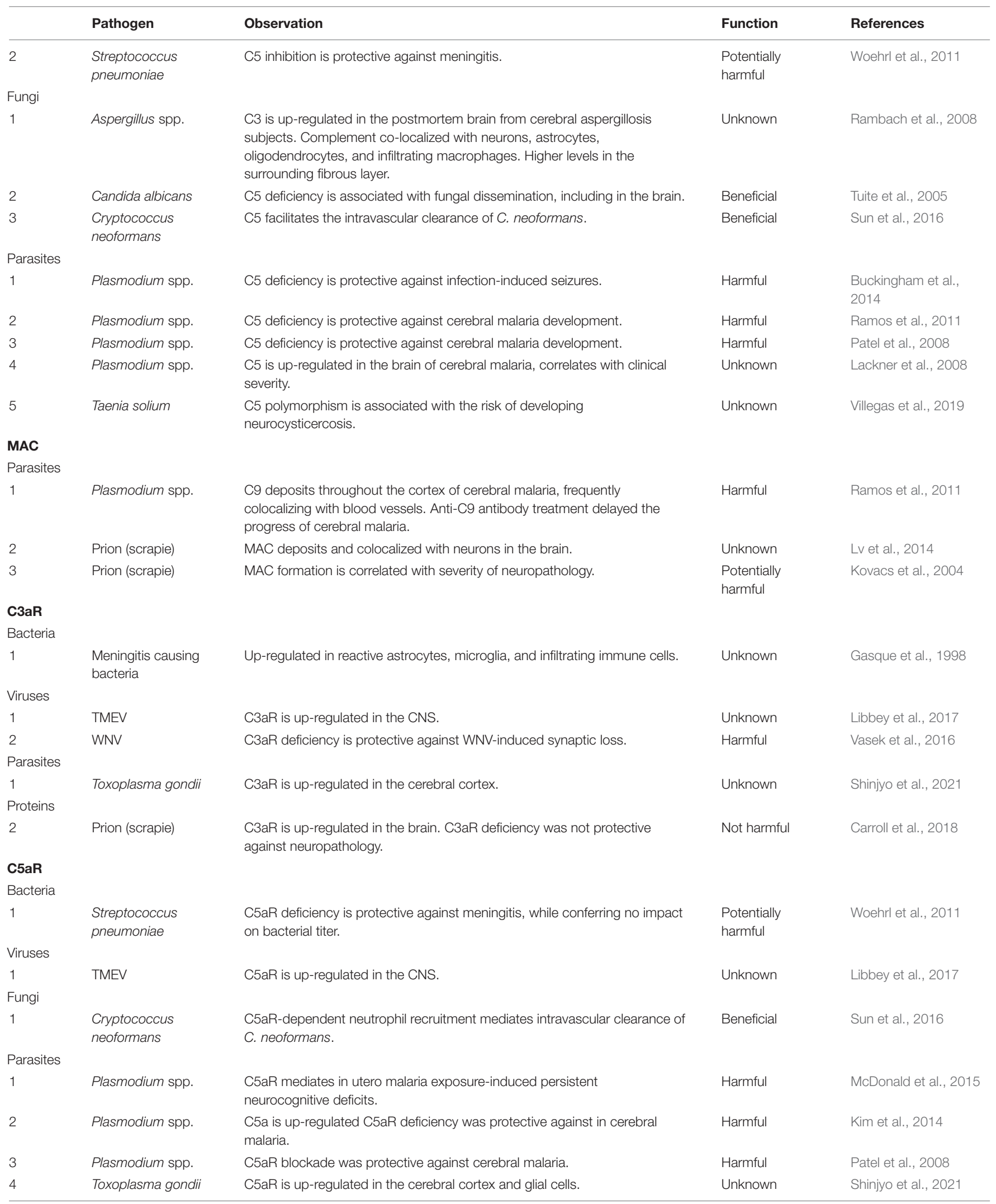

(Continued) 
TABLE 2 | Continued

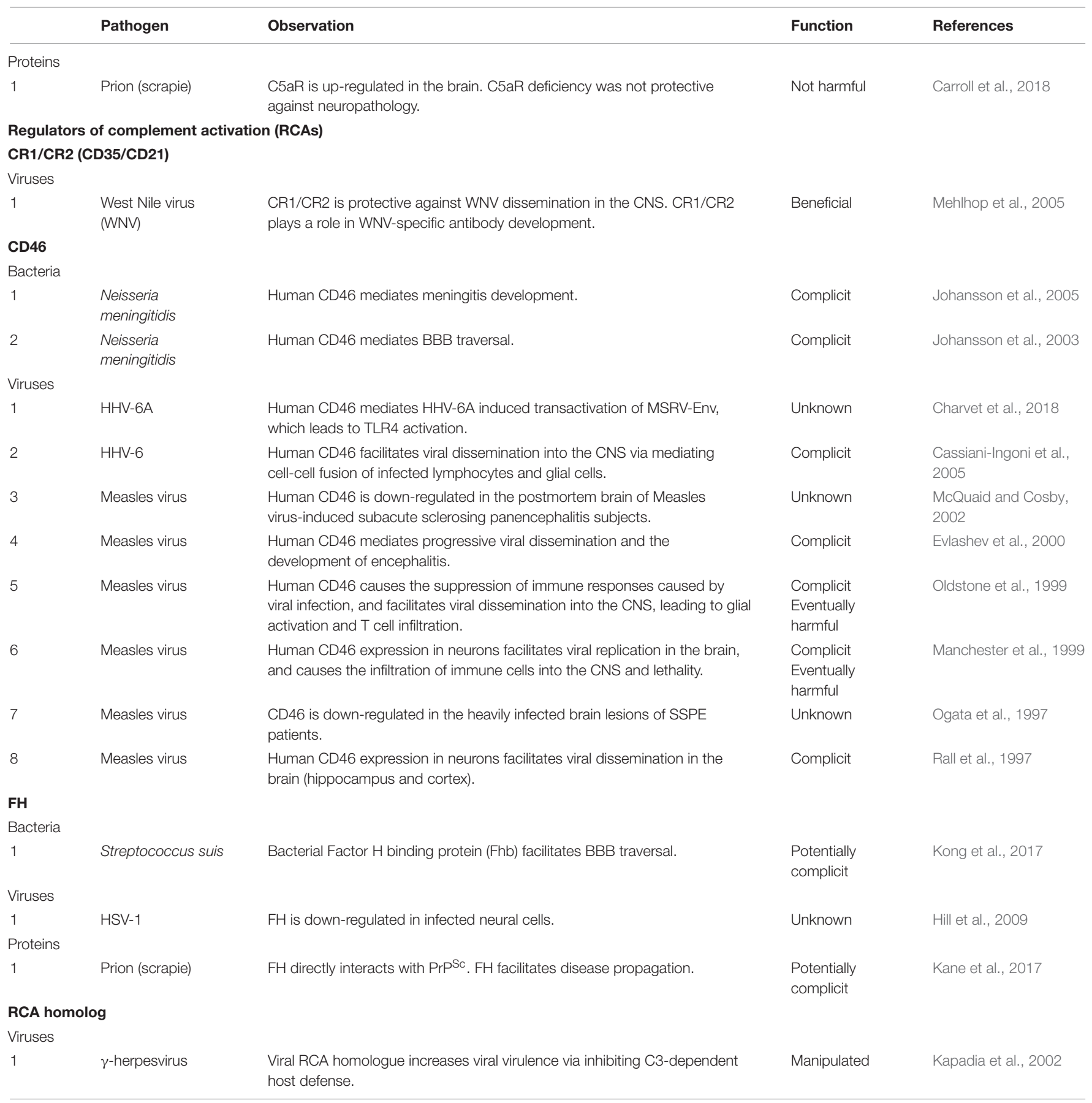

The relevant complement proteins are highlighted in bold.

CM (Ramos et al., 2011), confirming the crucial role of terminal complement pathway in $\mathrm{CM}$ pathogenesis. C3aR was up-regulated in the brain upon viral infection (Libbey et al., 2017) and C3aR deficiency was protective against viral infectioninduced synaptic loss (Vasek et al., 2016). C5aR deficiency was also protective against CM development (Patel et al., 2008; Kim et al., 2014; McDonald et al., 2015), as well as bacterial meningitis (Woehrl et al., 2011). However, neither $\mathrm{C} 3 \mathrm{aR}$ deficiency nor $\mathrm{C} 5 \mathrm{aR}$ deficiency were protective against prion-induced neuropathology (Carroll et al., 2018), indicating pathogen-specific roles of anaphylatoxin receptors in the CNS.

$\mathrm{CD} 46$, a negative regulator of the classical and lectin pathways, aids in the dissemination of bacteria (N. meningitidis) (Johansson et al., 2003, 2005) and viruses [Measles virus (Rall et al., 1997; Manchester et al., 1999; Oldstone et al., 1999; Evlashev et al., 2000) and HHV-6 (Cassiani-Ingoni et al., 2005)] into the CNS, leading to meningitis and encephalitis, respectively. While the use of CD46 by these pathogens could be an evasion strategy 
(B) The web of interactions between infection and complement (C)

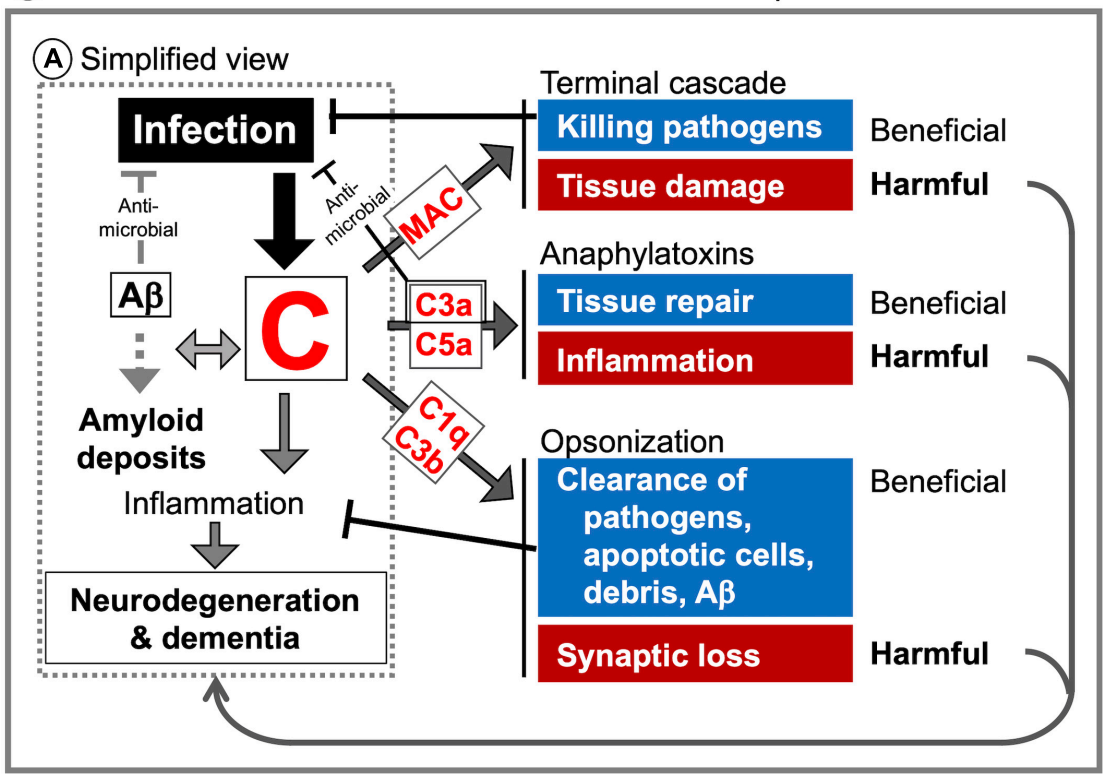

FIGURE 3 | Infection-induced complement activation in the CNS and potential links to neurodegeneration and dementia. (A) The most simplified view of how CNS infection can lead to neurodegeneration and dementia is enclosed in the dotted rectangle. Infection-induced complement activation products may contribute to neurodegeneration and dementia via interaction with amyloid deposits and enhanced neuroinflammation. (B) A more detailed schematic representation of specific interactions between infectious agents and the complement system as a potential mechanistic link between CNS infection, neurodegeneration and dementia. The consequences of complement activation may be context-dependent. For example, MAC plays a role in pathogen elimination but can also contribute to tissue damage. C3a and C5a can support tissue repair and adaptive neural plasticity, but also promote potentially detrimental inflammation and leukocyte recruitment. Opsonization and phagocytosis are needed for clearance of pathogens, but the same mechanisms are involved in synapse elimination as the first step in neurodegeneration.

from the classical or lectin pathway-mediated clearance, CD46dependent facilitation of immune cell infiltration into the CNS (Manchester et al., 1999; Oldstone et al., 1999) and cell-cell fusion of infected lymphocytes and glial cells (Cassiani-Ingoni et al., 2005) suggest higher mechanistic complexity of the interactions between complement and infectious agents. FH, a negative regulator of the alternative pathway, is also engaged in the dissemination of pathogens in bacterial (S. suis) (Kong et al., 2017) and prion infections (Kane et al., 2017), indicating that these infectious agents manipulate the alternative complement pathway for their propagation in the brain. The fact that a viral RCA homolog plays a facilitatory role in viral dissemination via the inhibition of C3-dependent host defense (Kapadia et al., 2002) suggests that infectious agents have evolved diverse molecular mechanisms to escape complement-mediated killing.

\section{DISCUSSION}

\section{Potential Link Between Infection-Induced Complement Activation and Dementia}

Considering the link between cognitive impairment and aberrant complement activation in the CNS (Aiyaz et al., 2012; Rubio-Perez and Morillas-Ruiz, 2012), the most simplified view is that CNS infection could lead to dementia via the complement activation (Figure 3A: dotted rectangle). However, as discussed above, the mechanistic links between infectious agents, complement, and neurodegeneration are far more complex. Due to the multiple neurodevelopmental and homeostatic functions that the complement system and its individual components play in the brain (Figure 1), complement activation by infectious agents can cause an imbalance in the intricate web of interactions between complement proteins and the nervous system with deleterious consequences for CNS tissue integrity and function (Figure 3B: solid rectangle). This could explain the unpredictable and sometimes inconsistent observations in different studies in human patients as well as in animal models of CNS infection. The multiple functions of the complement system in the CNS together with the complexity of immune responses to infection call for well-informed and highly selective approaches when manipulating the complement system for therapeutic benefit. For example, inhibiting the downstream of complement cascade (C5 and MAC) and/or C5aR could protect the brain from Plasmodium infection-induced tissue damage (Patel et al., 2008; Ramos et al., 2011; Buckingham et al., 2014; Kim et al., 2014), whereas inhibition restricted to the upstream components $(\mathrm{C} 1 \mathrm{q}, \mathrm{C} 2$, and $\mathrm{FB}$ ) could be beneficial in prion diseases (Klein et al., 2001), as shown in animal models. However, these studies were conducted using constitutive inactivation of specific genes. As the complement 
system plays multiple roles in the CNS, roles which are distinct from those in the periphery, it is imperative to investigate CNS-specific roles of the complement system in the context of an infection by a specific pathogen. Furthermore, while complement proteins are locally produced in the brain, it is less clear which cell types are responsible, how complement protein production and responses are regulated, and how are these processes influenced by various stimuli under physiological and pathological conditions, including CNS infection. Of particular interest in this respect are the potential functions of intracellular C3 (Elvington et al., 2016), not only with regard to the interactions between infectious agents and the brain-resident cells but also the role of intracellular C3 in neurodegeneration. Considering the diverse roles of glial cells (astrocytes and microglia, the brain-resident macrophages) in the maintenance of CNS homeostasis, further studies are required to elucidate how infectious agents modulate complement generation in glial cells and how, in turn, it might affect the phenotypes of these cells.

\section{CONCLUSION}

Of the approximately 50 million people with dementia worldwide, about $50 \%$ live in low- and middle-income countries (WHO, 2019). Considering higher risk of infection and infection-induced brain disorders in those countries (Fernandes and Caramelli, 2019; Singh et al., 2020), understanding of the potential mechanistic links between infection and neurodegenerative disorders including dementia, will inform the development of preventive and therapeutic strategies. While amyloidogenesis is widely accepted as the underlying cause of $\mathrm{AD}$ and other forms of neurodegenerative diseases, $\mathrm{A} \beta$-targeting drug development has been so far unsuccessful (Robakis, 2020). Given that the presence of amyloid plaques does not necessarily indicate cognitive decline (Skaper, 2012; Robakis, 2020), alternative culprits and theories are needed. Indeed, there is a growing body of evidence showing that innate immunity and neuroinflammation play a pivotal role in dementia development (Leng and Edison, 2020).

Separated from the other parts of the body by the BBB and CSF barrier, the CNS is uniquely protected by special immune components, including the complement system and glial cells. While locally produced complement components play crucial homeostatic roles in the CNS, dysregulated complement activity could be detrimental to the function

\section{REFERENCES}

Aiyaz, M., Lupton, M., Proitsi, P., Powell, J., and Lovestone, S. (2012). Complement activation as a biomarker for Alzheimer's disease. Immunobiology 217, 204-215. doi: 10.1016/j.imbio.2011.07.023

Alonso, R., Marina, D., Morato, A., Rábano, E., Carrasco, A., and Pisa, L. (2014). Fungal infection in patients with Alzheimer's disease. J. Alzheimers Dis. 41, 301-311. doi: 10.3233/JAD-132681

Alonso, R., Pisa, D., Fernández-Fernández, A., and Carrasco, L. (2018). Infection of fungi and bacteria in brain tissue from elderly persons and patients with Alzheimer's disease. Front. Aging Neurosci. 10:159. doi: 10.3389/fnagi.2018. 00159 of the CNS. As the key element of brain-resident innate immunity, the complement system plays both protective and destructive roles in neurodegeneration (Kolev et al., 2009). Whereas aberrant complement activation is frequently associated with neuroinflammation and neurodegenerative disorders, the complement system exerts homeostatic functions via eliminating apoptotic cells, cell debris, and toxic substances, and supports plasticity and tissue repair. A broad range of infectious agents can potentially interact with the complement system in the brain and the net outcome of these interactions appears to depend on the specific pathogens, the target components, and the mode of interaction. It is therefore conceivable that pathogen-triggered and persistent activation of the complement system represents the missing mechanistic link between infection, in particular infection affecting the CNS, and neurodegeneration. We are fully aware that the simplified view presented in Figure 3 does not capture every aspect of the involvement of the complement system in infection-induced neuropathology and neurodegeneration, but only highlights the key components of the interplay between pathogens and complement activation induced-neurodegenerative processes that may lead to dementia. While the specific mechanistic links between CNS infection, neurodegeneration and dementia are still unclear, the involvement of the complement system and the pathogen- and disease stage-specific roles of the individual complement proteins warrant further intense investigation.

\section{AUTHOR CONTRIBUTIONS}

NS wrote the first draft of the manuscript. MP and WK critically assessed the content. NS and MP jointly revised and finalized the manuscript. All the authors contributed to the article and approved the submitted version.

\section{FUNDING}

MP's research was supported by the Swedish Research Council (2017-00991), Hjärnfonden/The Swedish Brain Foundation, the Swedish state under the agreement between the Swedish Government and the county councils, the ALF agreement (716591), E. Jacobson's Foundation, and R. and U. Amlöv's Foundation. NS's research was supported by JSPS KAKENHI Grant No. 19K07839.

Alvarez-Lafuente, R., García-Montojo, M., De las Heras, V., Bartolomé, M., and Arroyo, R. (2006). Clinical parameters and HHV-6 active replication in relapsing-remitting multiple sclerosis patients. J. Clin. Virol. 37, S24-S26. doi: 10.1016/S1386-6532(06)70007-5

Amara, U., Flierl, M., Rittirsch, D., Klos, A., Chen, H., Acker, B., et al. (2010). Molecular interacommunication between the complement and coagulation systems. J. Immunol. 185, 5628-5636. doi: 10.4049/jimmunol.090 3678

Andrews, J., Cho-Park, Y., Ferry, J., Abramson, J., and Robbins, G. (2011). Kaposi's sarcoma-associated herpesvirus-related solid lymphoma involving the heart and brain. AIDS Res. Treat. 2011:729854. doi: 10.1155/2011/ 729854 
Araujo, F., Rosenberg, L., and Remington, J. (1975). Experimental Toxoplasma gondii infection in mice: the role of the fifth component of complement. Proc. Soc. Exp. Biol. Med. 149, 800-804. doi: 10.3181/00379727149-38902

Armah, H., Wang, G., Omalu, B., Tesh, R., Gyure, K., Chute, D., et al. (2007). Systemic distribution of West Nile virus infection: postmortem immunohistochemical study of six cases. Brain Pathol. 17, 354-362. doi: 10. 1111/j.1750-3639.2007.00080.x

Avalos, C., Abreu, C., Queen, S., Li, M., Price, S., Shirk, E., et al. (2017). Brain macrophages in simian immunodeficiency virus-infected, antiretroviralsuppressed macaques: a functional latent reservoir. mBio 8:e01186-17. doi: 10. 1128/mBio.01186- 17

Baldini, F., Baiocchini, A., Schininà, V., Agrati, C., Giancola, M., Alba, L., et al. (2013). Brain localization of Kaposi's sarcoma in a patient treated by combination antiretroviral therapy. BMC Infect Dis. 13:600. doi: 10.1186/14712334-13-600

Barnum, S., Ames, R., Maycox, P., Hadingham, S., Meakin, J., Harrison, D., et al. (2002). Expression of the complement C3a and C5a receptors after permanent focal ischemia: an alternative interpretation. Glia 38, 169-173. doi: 10.1002/glia. 10069

Behnke, M., Khan, A., Wootton, J., Dubey, J., Tang, K., and Sibley, L. (2011). Virulence differences in Toxoplasma mediated by amplification of a family of polymorphic pseudokinases. Proc. Natl. Acad. Sci. U.S.A. 108, 9631-9636. doi: 10.1073/pnas.1015338108

Bi, D., Qiao, L., Bergelson, I., Ek, C., Duan, L., Zhang, X., et al. (2015). Staphylococcus epidermidis bacteremia induces brain injury in neonatal mice via toll-like receptor 2-dependent and -independent pathways. J. Infect. Dis. 212, 1480-1490. doi: 10.1093/infdis/jiv231

Bibert, S., Piret, J., Quinodoz, M., Collinet, E., Zoete, V., Michielin, O., et al. (2019). Herpes simplex encephalitis in adult patients with MASP-2 deficiency. PLoS Pathog. 15:e1008168. doi: 10.1371/journal.ppat.1008168

Bigna, J., Tochie, J., Tounouga, D., Bekolo, A., Ymele, N., Youda, E., et al. (2020). Global, regional, and country seroprevalence of Toxoplasma gondii in pregnant women: a systematic review, modelling and meta-analysis. Sci. Rep. 10:12102. doi: 10.1038/s41598-020-69078-9

Bonifati, D., and Kishore, U. (2007). Role of complement in neurodegeneration and neuroinflammation. Mol. Immunol. 44, 999-1010. doi: 10.1016/j.molimm. 2006.03.007

Bossolasco, S., Falk, K., Ponzoni, M., Ceserani, N., Crippa, F., Lazzarin, A., et al. (2006). Ganciclovir is associated with low or undetectable Epstein-Barr virus DNA load in cerebrospinal fluid of patients with HIV-related primary central nervous system lymphoma. Clin. Infect. Dis. 42, e21-e25.

Brennan, F., Jogia, T., Gillespie, E., Blomster, L., Li, X., Nowlan, B., et al. (2019). Complement receptor $\mathrm{C} 3 \mathrm{aR} 1$ controls neutrophil mobilization following spinal cord injury through physiological antagonism of CXCR2. JCI Insight 4:e98254. doi: $10.1172 /$ jci.insight. 98254

Bridges, D., Bunn, J., van Mourik, J., Grau, G., Preston, R., and Molyneux, M. (2010). Rapid activation of endothelial cells enables Plasmodium falciparum adhesion to platelet-decorated von Willebrand factor strings. Blood 115, 14721474. doi: 10.1182/blood-2009-07-235150

Brito Ferreira, M., Antunes de Brito, C., Moreira, Á, de Morais Machado, M., Henriques-Souza, A., Cordeiro, M., et al. (2017). Guillain-Barré syndrome, acute disseminated encephalomyelitis and encephalitis associated with zika virus infection in Brazil: detection of viral RNA and isolation of virus during late infection. Am. J. Trop. Med. Hyg. 97, 1405-1409. doi: 10.4269/ajtmh.17-0106

Brooke, C., Schäfer, A., Matsushima, G., White, L., and Johnston, R. (2012). Early activation of the host complement system is required to restrict central nervous system invasion and limit neuropathology during Venezuelan equine encephalitis virus infection. J. Gen. Virol. 93, 797-806. doi: 10.1099/vir.0. 038281-0

Brouwer, M., de Gans, J., Heckenberg, S., Zwinderman, A., van der Poll, T., and van de Beek, D. (2009). Host genetic susceptibility to pneumococcal and meningococcal disease: a systematic review and meta-analysis. Lancet Infect. Dis. 9, 31-44. doi: 10.1016/S1473-3099(08)70261-5

Brown, K., Stewart, K., Ritchie, D., Mabbott, N., Williams, A., Fraser, H., et al. (1999). Scrapie replication in lymphoid tissues depends on prion proteinexpressing follicular dendritic cells. Nat. Med. 5, 1308-1312. doi: 10.1038/ 15264
Buckingham, S., Ramos, T., and Barnum, S. (2014). Complement C5-deficient Mice are protected from seizures in experimental cerebral malaria. Epilepsia 55 , e139-e142.

Budka, H. (2000). Histopathology and immunohistochemistry of human transmissible spongiform encephalopathies (TSEs). Arch. Virol. Suppl. 16, 135142. doi: 10.1007/978-3-7091-6308-5_12

Cadman, E., and Puttfarcken, P. (1997). Beta-amyloid peptides initiate the complement cascade without producing a comparable effect on the terminal pathway in vitro. Exp. Neurol. 146, 388-394. doi: 10.1006/exnr.1997. 6540

Carbone, I., Lazzarotto, T., Ianni, M., Porcellini, E., Forti, P., Masliah, E., et al. (2014). Herpes virus in Alzheimer's disease: relation to progression of the disease. Neurobiol. Aging 35, 122-129. doi: 10.1016/j.neurobiolaging.2013.06. 024

Carlson, J. (1993). Erythrocyte rosetting in Plasmodium falciparum malaria-with special reference to the pathogenesis of cerebral malaria. Scand. J. Infect. Dis. Suppl. 86, 1-79.

Carroll, J., Race, B., Williams, K., and Chesebro, B. (2018). Toll-like receptor 2 confers partial neuroprotection during prion disease. PLoS One 13:e0208559. doi: 10.1371/journal.pone. 0208559

Cassiani-Ingoni, R., Greenstone, H., Donati, D., Fogdell-Hahn, A., Martinelli, E., Refai, D., et al. (2005). CD46 on glial cells can function as a receptor for viral glycoprotein-mediated cell-cell fusion. Glia 52, 252-258. doi: 10.1002/glia. 20219

Charvet, B., Reynaud, J., Gourru-Lesimple, G., Perron, H., Marche, P., and Horvat, B. (2018). Induction of proinflammatory multiple sclerosisassociated retrovirus envelope protein by human herpesvirus-6A and CD46 receptor engagement. Front. Immunol. 9:2803. doi: 10.3389/fimmu.2018. 02803

Chen, C., Lv, Y., Hu, C., Xu, X., Zhang, R., Xiao, K., et al. (2020). Alternative complement pathway is activated in the brains of scrapie-infected rodents. Med. Microbiol. Immunol. 209, 81-94. doi: 10.1007/s00430-019-00641-6

Chen, C., Lv, Y., Shi, Q., Zhou, W., Xiao, K., Sun, J., et al. (2016). Low activity of complement in the cerebrospinal fluid of the patients with various prion diseases. Infect. Dis. Poverty 5:35. doi: 10.1186/s40249-016-0128-7

Clarke, P., Leser, J., Quick, E., Dionne, K., Beckham, J., and Tyler, K. (2014). Death receptor-mediated apoptotic signaling is activated in the brain following infection with West Nile virus in the absence of a peripheral immune response. J. Virol. 88, 1080-1089. doi: 10.1128/JVI.02944-13

Clifford, D. (2017). HIV-associated neurocognitive disorder. Curr. Opin. Infect. Dis. 30, 117-122. doi: 10.1097/QCO.0000000000000328

Cockburn, I., Mackinnon, M., O’Donnell, A., Allen, S., Moulds, J., Baisor, M., et al. (2004). A human complement receptor 1 polymorphism that reduces Plasmodium falciparum rosetting confers protection against severe malaria. Proc. Natl. Acad. Sci. U.S.A. 101, 272-277. doi: 10.1073/pnas.0305306101

Coulthard, L., Hawksworth, O., Conroy, J., Lee, J., and Woodruff, T. (2018). Complement C3a receptor modulates embryonic neural progenitor cell proliferation and cognitive performance. Mol. Immunol. 101, 176-181. doi: 10.1016/j.molimm.2018.06.271

Coulthard, L., and Woodruff, T. (2015). Is the complement activation product C3a a proinflammatory molecule? Re-evaluating the evidence and the myth. J. Immunol. 194, 3542-3548. doi: 10.4049/jimmunol.1403068

Czirr, E., Castello, N., Mosher, K., Castellano, J., Hinkson, I., Lucin, K., et al. (2017). Microglial complement receptor 3 regulates brain Abeta levels through secreted proteolytic activity. J. Exp. Med. 214, 1081-1092. doi: 10.1084/jem.2016 2011

Dandoy-Dron, F., Benboudjema, L., Guillo, F., Jaegly, A., Jasmin, C., Dormont, D., et al. (2000). Enhanced levels of scrapie responsive gene mRNA in BSEinfected mouse brain. Brain Res. Mol. Brain Res. 76, 173-179. doi: 10.1016/ s0169-328x (00)00028-0

Dandoy-Dron, F., Guillo, F., Benboudjema, L., Deslys, J., Lasmézas, C., Dormont, D., et al. (1998). Gene expression in scrapie. Cloning of a new scrapie-responsive gene and the identification of increased levels of seven other mRNA transcripts. J. Biol. Chem. 273, 7691-7697. doi: 10.1074/jbc.273.13.7691

Davila, S., Wright, V., Khor, C., Sim, K., Binder, A., Breunis, W., et al. (2010). Genome-wide association study identifies variants in the $\mathrm{CFH}$ region associated with host susceptibility to meningococcal disease. Nat. Genet. 42, 772-776. doi: $10.1038 /$ ng. 640 
Del Grande, C., Galli, L., Schiavi, E., Dell'Osso, L., and Bruschi, F. (2017). Is Toxoplasma gondii a trigger of bipolar disorder? Pathogens 6:3. doi: 10.3390/ pathogens6010003

Dempsey, P., Allison, M., Akkaraju, S., Goodnow, C., and Fearon, D. (1996). C3d of complement as a molecular adjuvant: bridging innate and acquired immunity. Science 271, 348-350. doi: 10.1126/science.271.5247.348

Depboylu, C., Schäfer, M., Schwaeble, W., Reinhart, T., Maeda, H., Mitsuya, H., et al. (2005). Increase of C1q biosynthesis in brain microglia and macrophages during lentivirus infection in the rhesus macaque is sensitive to antiretroviral treatment with 6-chloro- $2^{\prime}, 3^{\prime}$-dideoxyguanosine. Neurobiol. Dis. 20, 12-26. doi: 10.1016/j.nbd.2005.01.030

Dietzschold, B., Schwaeble, W., Schäfer, M., Hooper, D., Zehng, Y., Petry, F., et al. (1995). Expression of C1q, a subcomponent of the rat complement system, is dramatically enhanced in brains of rats with either Borna disease or experimental allergic encephalomyelitis. J. Neurol. Sci. 130, 11-16. doi: 10.1016/ 0022-510x(94)00269-t

Dominguez-Punaro, M., Segura, M., Plante, M., Lacouture, S., Rivest, S., and Gottschalk, M. (2007). Streptococcus suis serotype 2, an important swine and human pathogen, induces strong systemic and cerebral inflammatory responses in a mouse model of infection. J. Immunol. 179, 1842-1854. doi: 10.4049/ jimmunol.179.3.1842

Dunst, J., Kamena, F., and Matuschewski, K. (2017). Cytokines and chemokines in cerebral malaria pathogenesis. Front. Cell Infect. Microbiol. 7:324. doi: 10.3389/ fcimb.2017.00324

Eikelenboom, P., Bate, C., Van Gool, W., Hoozemans, J., Rozemuller, J., Veerhuis, R., et al. (2002). Neuroinflammation in Alzheimer's disease and prion disease. Glia 40, 232-239. doi: 10.1002/glia.10146

Eikelenboom, P., Hack, C., Rozemuller, J., and Stam, F. (1989). Complement activation in amyloid plaques in Alzheimer's dementia. Virchows Arch. B Cell Pathol. Incl. Mol. Pathol. 56, 259-262. doi: 10.1007/BF02890024

Elsheikha, H., Büsselberg, D., and Zhu, X. (2016). The known and missing links between Toxoplasma gondii and schizophrenia. Metab. Brain Dis. 31, 749-759. doi: 10.1007/s11011-016-9822-1

Elvington, M., Liszewski, M., and Atkinson, J. (2016). Evolution of the complement system: from defense of the single cell to guardian of the intravascular space. Immunol. Rev. 274, 9-15. doi: 10.1111/imr.12474

Evlashev, A., Moyse, E., Valentin, H., Azocar, O., Trescol-Biémont, M., Marie, J., et al. (2000). Productive measles virus brain infection and apoptosis in CD46 transgenic mice. J. Virol. 74, 1373-1382. doi: 10.1128/jvi.74.3.1373-1382.2000

Farriesa, T., and Atkinson, J. (1991). Evolution of the complement system. Immunol. Today 12, 295-300. doi: 10.1016/0167-5699(91)90002-B

Fernandes, B., and Caramelli, P. (2019). Ischemic stroke and infectious diseases in low-income and middle-income countries. Curr. Opin. Neurol. 32, 43-48. doi: 10.1097/WCO.0000000000000641

Figueiredo, C., Barros-Aragão, F., Neris, R., Frost, P., Soares, C., Souza, I., et al. (2019). Zika virus replicates in adult human brain tissue and impairs synapses and memory in mice. Nat. Commun. 10:3890. doi: 10.1038/s41467-01911866-7

Fijen, C., van den Bogaard, R., Schipper, M., Mannens, M., Schlesinger, M., Nordin, F., et al. (1999). Properdin deficiency: molecular basis and disease association. Mol. Immunol. 36, 863-867. doi: 10.1016/s0161-5890(99)00107-8

Finley, R., Mackey, L., and Lambert, P. (1982). Virulent P. berghei malaria: prolonged survival and decreased cerebral pathology in cell-dependent nude mice. J. Immunol. 1219, 2213-2218.

Flores-Langarica, A., Sebti, Y., Mitchell, D., Sim, R., and MacPherson, G. (2009). Scrapie pathogenesis: the role of complement $\mathrm{Clq}$ in scrapie agent uptake by conventional dendritic cells. J. Immunol. 182, 1305-1313. doi: 10.4049/ jimmunol.182.3.1305

Fodor, W., Rollins, S., Bianco-Caron, S., Rother, R., Guilmette, E., Burton, W., et al. (1995). The complement control protein homolog of herpesvirus saimiri regulates serum complement by inhibiting C3 convertase activity. J. Virol. 69, 3889-3892. doi: 10.1128/JVI.69.6.3889-3892.1995

Fond, G., Boyer, L., Schürhoff, F., Berna, F., Godin, O., Bulzacka, E., et al. (2018). Latent Toxoplasma infection in real-world schizophrenia: results from the national FACE-SZ cohort. Schizophr Res. S0920, 30262-30265. doi: 10.1016/j. schres.2018.05.007

Francischetti, I. (2008). Does activation of the blood coagulation cascade have a role in malaria pathogenesis? Trends Parasitol. 24, 258-263. doi: 10.1016/j.pt. 2008.03.009
Frevert, U., and Nacer, A. (2014). Fatal cerebral malaria: a venous efflux problem. Front. Cell Infect. Microbiol. 4:155. doi: 10.3389/fcimb.2014.00155

Fu, H., Liu, B., Frost, J., Hong, S., Jin, M., Ostaszewski, B., et al. (2012). Complement component $\mathrm{C} 3$ and complement receptor type 3 contribute to the phagocytosis and clearance of fibrillar A $\beta$ by microglia. Glia 60, 993-1003. doi: 10.1002/glia. 22331

Fuglewicz, A., Piotrowski, P., and Stodolak, A. (2017). Relationship between toxoplasmosis and schizophrenia: a review. Adv. Clin. Exp. Med. 26, 10311036.

Fuhrman, S., and Joiner, K. (1989). Toxoplasma gondii: mechanism of resistance to complement-mediated killing. J. Immunol. 142, 940-947.

Garred, P., Tenner, A., and Mollnes, T. (2021). Therapeutic targeting of the complement system: from rare diseases to pandemics. Pharmacol. Rev. 73, 792-827. doi: 10.1124/pharmrev.120.000072

Gasque, P., Dean, Y., McGreal, E., VanBeek, J., and Morgan, B. (2000). Complement components of the innate immune system in health and disease in the CNS. Immunopharmacology 49, 171-186. doi: 10.1016/s0162-3109(00) 80302-1

Gasque, P., Singhrao, S. K., Neal, J. W., Wang, P., Sayah, S., Fontaine, M., et al. (1998). The receptor for complement anaphylatoxin C3a is expressed by myeloid cells and nonmyeloid cells in inflamed human central nervous system: analysis in multiple sclerosis and bacterial meningitis. J. Immunol. 160, 3543-3554.

Glatzel, M., Heppner, F., Albers, K., and Aguzzi, A. (2001). Sympathetic innervation of lymphoreticular organs is rate limiting for prion neuroinvasion. Neuron 31, 25-34. doi: 10.1016/s0896-6273(01) 00331-2

Gomez-Gutierrez, R., and Morales, R. (2020). The prion-like phenomenon in Alzheimer's disease: evidence of pathology transmission in humans. PLoS Pathog. 16:e1009004. doi: 10.1371/journal.ppat.1009004

Góralska, K., Blaszkowska, J., and Dzikowiec, M. (2018). Neuroinfections caused by fungi. Infection 46, 443-459. doi: 10.1007/s15010-018-1152-2

Gorelik, A., Sapir, T., Haffner-Krausz, R., Olender, T., Woodruff, T., and Reiner, O. (2017). Developmental activities of the complement pathway in migrating neurons. Nat. Commun. 8:15096. doi: 10.1038/ncomms15096

Gottfredsson, M., and Perfect, J. (2000). Fungal meningitis. Semin. Neurol. 20, 307-322. doi: 10.1055/s-2000-9394

Granoff, D., Welsch, J., and Ram, S. (2009). Binding of complement factor H (fH) to Neisseria meningitidis is specific for human $\mathrm{fH}$ and inhibits complement activation by rat and rabbit sera. Infect. Immun. 77, 764-769. doi: 10.1128/IAI. 01191-08

Grau, G., Mackenzie, C., Carr, R., Redard, M., Pizzolato, G., Allasia, C., et al. (2003). Platelet accumulation in brain microvessels in fatal pediatric cerebral malaria. J. Infect. Dis. 187, 461-466. doi: 10.1086/367960

Graybill, J., Bocanegra, R., Lambros, C., and Luther, M. (1997). Granulocyte colony stimulating factor therapy of experimental cryptococcal meningitis. J. Med. Vet. Mycol. 35, 243-247. doi: 10.1080/02681219780001221

Griffin, D. (2020). Measles virus persistence and its consequences. Curr. Opin. Virol. 41, 46-51. doi: 10.1016/j.coviro.2020.03.003

Hammond, J., Qiu, W., Marker, D., Chamberlain, J., Greaves-Tunnell, W., Bellizzi, M., et al. (2018). HIV Tat causes synapse loss in a mouse model of $\mathrm{HIV}$-associated neurocognitive disorder that is independent of the classical complement cascade component C1q. Glia 66, 2563-2574. doi: 10.1002/glia. 23511

Haralambous, E., Dolly, S., Hibberd, M., Litt, D., Udalova, I., O'dwyer, C., et al. (2006). Factor H, a regulator of complement activity, is a major determinant of meningococcal disease susceptibility in UK Caucasian patients. Scand. J. Infect. Dis. 38, 764-771. doi: 10.1080/00365540600643203

Hartmann, K., Sepulveda-Falla, D., Rose, I., Madore, C., Muth, C., Matschke, J., et al. (2019). Complement 3(+)-astrocytes are highly abundant in prion diseases, but their abolishment led to an accelerated disease course and early dysregulation of microglia. Acta Neuropathol. Commun. 7:83. doi: 10.1186/ s40478-019-0735-1

Hasebe, R., Raymond, G., Horiuchi, M., and Caughey, B. (2012). Reaction of complement factors varies with prion strains in vitro and in vivo. Virology 423, 205-213. doi: 10.1016/j.virol.2011.11.017

Henriquez, S., Brett, R., Alexander, J., Pratt, J., and Roberts, C. (2009). Neuropsychiatric disease and Toxoplasma gondii infection. Neuroimmunomodulation 16, 122-133. doi: 10.1159/000180267 
Hill, J., Zhao, Y., Clement, C., Neumann, D., and Lukiw, W. (2009). HSV1 infection of human brain cells induces miRNA-146a and Alzheimertype inflammatory signaling. Neuroreport 20, 1500-1505. doi: 10.1097/WNR. 0b013e3283329c05

Hong, S., Beja-Glasser, V., Nfonoyim, B., Frouin, A., Li, S., Ramakrishnan, S., et al. (2016). Complement and microglia mediate early synapse loss in Alzheimer mouse models. Science 352, 712-716. doi: 10.1126/science. aad 8373

Howe, D., and Sibley, L. (1995). Toxoplasma gondii comprises three clonal lineages: correlation of parasite genotype with human disease. J. Infect. Dis. 172, 15611566. doi: 10.1093/infdis/172.6.1561

Huang, W., Wang, Y., Mahmmod, Y., Wang, J., Liu, T., Zheng, Y., et al. (2019). A double-edged sword: complement component 3 in Toxoplasma gondii infection. Proteomics 19, e1800271. doi: 10.1002/pmic.201800271

Idro, R., Marsh, K., John, C., and Newton, C. (2010). Europe PMC funders group cerebral malaria?; mechanisms of brain injury and strategies for improved neuro-cognitive outcome. Pediatr. Res. 68, 267-274. doi: 10.1203/00006450201011001-00524

Ischenko, A., Sayah, S., Patte, C., Andreev, S., Gasque, P., Schouft, M. T., et al. (1998). Expression of a functional anaphylatoxin C3a receptor by astrocytes. J. Neurochem. 71, 2487-2496.

Itzhaki, R. (2018). Corroboration of a Major role for herpes simplex virus type 1 in Alzheimer's disease. Front. Aging Neurosci. 10:324. doi: 10.3389/fnagi.2018. 00324

Ivanova, D., Denton, S., Fettel, K., Sondgeroth, K., Munoz Gutierrez, J., Bangoura, B., et al. (2019). Innate lymphoid cells in protection, pathology, and adaptive immunity during apicomplexan infection. Front. Immunol. 10:196. doi: 10. 3389/fimmu.2019.00196

Johansson, L., Rytkonen, A., Bergman, P., Albiger, B., Källström, H., Hökfelt, T., et al. (2003). CD46 in meningococcal disease. Science 301, 373-375. doi: $10.1126 /$ science. 1086476

Johansson, L., Rytkönen, A., Wan, H., Bergman, P., Plant, L., Agerberth, B., et al. (2005). Human-like immune responses in CD46 transgenic mice. J. Immunol. 175, 433-440. doi: 10.4049/jimmunol.175.1.433

Johnson, U., Ohlsson, K., and Olsson, I. (1976). Effects of granulocyte neutral proteases on complement components. Scand. J. Immunol. 5, 421-426. doi: 10.1111/j.1365-3083.1976.tb00296.x

Jönsson, G., Truedsson, L., Sturfelt, G., Oxelius, V., Braconier, J., and Sjöholm, A. (2005). Hereditary C2 deficiency in Sweden: frequent occurrence of invasive infection, atherosclerosis, and rheumatic disease. Medicine 84, 23-34.

Kane, S., Farley, T., Gordon, E., Estep, J., Bender, H., Moreno, J., et al. (2017). Complement regulatory protein factor $\mathrm{H}$ Is a soluble prion receptor that potentiates peripheral prion pathogenesis. J. Immunol. 199, 3821-3827. doi: 10.4049/jimmunol.1701100

Kaneko, Y., Takashima, Y., Xuaun, X., Igarashi, I., Nagasawa, H., Mikami, T., et al. (2004). Natural IgM antibodies in sera from various animals but not the cat kill Toxoplasma gondii by activating the classical complement pathway. Parasitology 128, 123-129. doi: 10.1017/s0031182003004414

Kapadia, S., Levine, B., Speck, S., and Virgin, H. IV (2002). Critical role of complement and viral evasion of complement in acute, persistent, and latent gamma-herpesvirus infection. Immunity 17, 143-155. doi: 10.1016/s10747613(02)00369-2

Kapadia, S., Molina, H., van Berkel, V., Speck, S., and Virgin, H. IV (1999). Murine gammaherpesvirus 68 encodes a functional regulator of complement activation. J. Virol. 73, 7658-7670. doi: 10.1128/JVI.73.9.7658-7670.1999

Kennedy, A., Schmidt, C., Thompson, J., Weiss, G., Taechalertpaisarn, T., Gilson, P., et al. (2016). Recruitment of factor $\mathrm{H}$ as a novel complement evasion strategy for blood-stage Plasmodium falciparum infection. J. Immunol. 196, 1239-1248. doi: 10.4049/jimmunol.1501581

Kennedy, A., Wijeyewickrema, L., Huglo, A., Lin, C., Pike, R., Cowman, A., et al. (2017). Recruitment of human C1 esterase inhibitor controls complement activation on blood stage Plasmodium falciparum merozoites. J. Immunol. 198, 4728-4737. doi: 10.4049/jimmunol.1700067

Kim, H., Erdman, L., Lu, Z., Serghides, L., Zhong, K., Dhabangi, A., et al. (2014). Functional roles for C5a and C5aR but Not C5L2 in the pathogenesis of human and experimental cerebral malaria. Infect. Immun. 82, 371-379. doi: 10.1128/ IAI.01246-13

King, B., Renström, E., and Blom, A. (2019). Intracellular cytosolic complement component $\mathrm{C} 3$ regulates cytoprotective autophagy in pancreatic beta cells by interaction with ATG16L1. Autophagy 15, 919-921. doi: 10.1080/15548627. 2019.1580515

Klein, M., Kaeser, P., Schwarz, P., Weyd, H., Xenarios, I., Zinkernagel, R., et al. (2001). Complement facilitates early prion pathogenesis. Nat. Med. 7, 488-492. doi: $10.1038 / 86567$

Koelman, D., Brouwer, M., and van de Beek, D. (2019). Targeting the complement system in bacterial meningitis. Brain 142, 3325-3337. doi: 10.1093/brain/ awz222

Kolev, M., Ruseva, M., Harris, C., Morgan, B., and Donev, R. (2009). Implication of complement system and its regulators in Alzheimer's disease. Curr. Neuropharmacol. 7, 1-8. doi: 10.2174/157015909787602805

Kong, D., Chen, Z., Wang, J., Lv, Q., Jiang, H., Zheng, Y., et al. (2017). Interaction of factor H-binding protein of Streptococcus suis with globotriaosylceramide promotes the development of meningitis. Virulence 8, 1290-1302. doi: 10.1080/ 21505594.2017.1317426

Kovacs, G., Gasque, P., Ströbel, T., Lindeck-Pozza, E., Strohschneider, M., Ironside, J., et al. (2004). Complement activation in human prion disease. Neurobiol. Dis. 15, 21-28. doi: 10.1016/j.nbd.2003.09.010

Kraiczy, P., Skerka, C., Kirschfink, M., Brade, V., and Zipfel, P. (2001). Immune evasion of Borrelia burgdorferi by acquisition of human complement regulators FHL-1/reconectin and Factor H. Eur. J. Immunol. 31, 1674-1684. doi: 10.1002/ 1521-4141(200106)31:6<1674::aid-immu1674<3.0.co;2-2

Kulkarni, H., Elvington, M., Perng, Y., Liszewski, M., Byers, D., Farkouh, C., et al. (2019). Intracellular C3 protects human airway epithelial cells from stressassociated cell death. Am. J. Respir. Cell Mol. Biol. 60, 144-157. doi: 10.1165/ rcmb.2017-0405OC

Kumar, M., Varun, C., Dey, G., Ravikumar, R., Mahadevan, A., Shankar, S., et al. (2018). Identification of host-response in cerebral malaria patients using quantitative proteomic analysis. Proteomics Clin. Appl. 12:e1600187. doi: 10. 1002/prca.201600187

Kwon, H., and Koh, S. (2020). Neuroinflammation in neurodegenerative disorders: the roles of microglia and astrocytes. Transl. Neurodegener. 9:42. doi: 10.1186/ s40035-020-00221-2

Lackner, P., Hametner, C., Beer, R., Burger, C., Broessner, G., Helbok, R., et al. (2008). Complement factors C1q, C3 and C5 in brain and serum of mice with cerebral malaria. Malar. J. 7:207. doi: 10.1186/1475-2875-7-207

Lalli, P., Strainic, M., Yang, M., Lin, F., Medof, M., and Heeger, P. (2008). Locally produced C5a binds to T cell-expressed C5aR to enhance effector T-cell expansion by limiting antigen-induced apoptosis. Blood 112, 1759-1766. doi: 10.1182/blood-2008-04-151068

Landlinger, C., Oberleitner, L., Gruber, P., Noiges, B., Yatsyk, K., Santic, R., et al. (2015). Active immunization against complement factor C5a: a new therapeutic approach for Alzheimer's disease. J. Neuroinflammation 12:50. doi: 10.1186/ s12974-015-0369-6

Leng, F., and Edison, P. (2020). Neuroinflammation and microglial activation in Alzheimer disease: where do we go from here? Nat. Rev. Neurol. 17, 157-172. doi: 10.1038/s41582-020-00435-y

Li, Y., Severance, E., Viscidi, R., Yolken, R., and Xiao, J. (2019). Persistent Toxoplasma infection of the brain induced neurodegeneration associated with activation of complement and microglia. Infect. Immun. 87:e00139-19. doi: 10.1128/IAI.00139-19

Libbey, J., Cusick, M., Doty, D., and Fujinami, R. (2017). Complement components are expressed by infiltrating macrophages/activated microglia early following viral infection. Viral Immunol. 30, 304-314. doi: 10.1089/vim.2016.0175

Lionakis, M., Lim, J., Lee, C., and Murphy, P. (2011). Organ-specific innate immune responses in a mouse model of invasive candidiasis. J. Innate Immun. 3, 180-199. doi: 10.1159/000321157

Liszewski, M., Elvington, M., Kulkarni, H., and Atkinson, J. (2017). Complement's hidden arsenal: New insights and novel functions inside the cell. Mol. Immunol. 84, 2-9. doi: 10.1016/j.molimm.2017.01.004

Liszewski, M., Farries, T., Lublin, D., Rooney, I., and Atkinson, J. (1996). Control of the complement system. Adv. Immunol. 61, 201-283. doi: 10.1016/s00652776(08)60868-8

Liszewski, M., Kolev, M., Le Friec, G., Leung, M., Bertram, P., Fara, A., et al. (2013). Intracellular complement activation sustains $\mathrm{T}$ cell homeostasis and mediates effector differentiation. Immunity 39, 1143-1157. doi: 10.1016/j.immuni.2013. 10.018

Liszewski, M., Leung, M., Cui, W., Subramanian, V., Parkinson, J., Barlow, P., et al. (2000). Dissecting sites important for complement regulatory activity in 
membrane cofactor protein (MCP; CD46). J. Biol. Chem. 275, 37692-37701. doi: 10.1074/jbc.M004650200

Liu, F., Dai, S., Gordon, J., and Qin, X. (2014). Complement and HIV-I infection/HIV-associated neurocognitive disorders. J. Neurovirol. 20, 184-198. doi: 10.1007/s13365-014-0243-9

Lovchik, J., and Lipscomb, M. (1993). Role for C5 and neutrophils in the pulmonary intravascular clearance of circulating Cryptococcus neoformans. Am. J. Respir. Cell Mol. Biol. 9, 617-627. doi: 10.1165/ajrcmb/9.6.617

Lv, Y., Chen, C., Zhang, B., Xiao, K., Wang, J., Chen, L., et al. (2014). Remarkable activation of the complement system and aberrant neuronal localization of the membrane attack complex in the brain tissues of scrapie-infected rodents. Mol. Neurobiol. 52, 1165-1179. doi: 10.1007/s12035-014-8915-2

Lyzogubov, V., Wu, X., Jha, P., Tytarenko, R., Triebwasser, M., Kolar, G., et al. (2014). Complement regulatory protein CD46 protects against choroidal neovascularization in mice. Am. J. Pathol. 184, 2537-2548. doi: 10.1016/j.ajpath. 2014.06.001

Mahmoud, M. E., Fereig, R., and Nishikawa, Y. (2017). Involvement of host defense mechanisms against Toxoplasma gondii infection in anhedonic and despair-like behaviors in mice. Infect. Immun. 85:e00007-17.

Manchester, M., Eto, D., and Oldstone, M. (1999). Characterization of the inflammatory response during acute measles encephalitis in NSE-CD46 transgenic mice. J. Neuroimmunol. 96, 207-217. doi: 10.1016/s0165-5728(99) 00036-3

Markiewski, M. M., and Lambris, J. D. (2007). The role of complement in inflammatory diseases from behind the scenes into the spotlight. Am. J. Pathol. 171, 715-727. doi: 10.2353/ajpath.2007.070166

Marra, C. (2018). Central nervous system infection with Toxoplasma gondii. Handb. Clin. Neurol. 152, 117-122. doi: 10.1016/B978-0-444-63849-6.00009-8

Mathern, D., and Heeger, P. (2015). Molecules great and small: the complement system. Clin. J. Am. Soc. Nephrol. 10, 1636-1650. doi: 10.2215/CJN.06230614

Matsuo, K., Shindo, A., Niwa, A., Tabei, K., Akatsu, H., Hashizume, Y., et al. (2017). Complement activation in capillary cerebral amyloid angiopathy. Dement. Geriatr. Cogn. Disord. 44, 343-353.

Matsushita, M., and Fujita, T. (1995). Cleavage of the third component of complement (C3) by mannose-binding protein-associated serine protease (MASP) with subsequent complement activation. Immunobiology 194, 443448. doi: 10.1016/S0171-2985(11)80110-5

Maury, A., Lyoubi, A., Peiffer-Smadja, N., de Broucker, T., and Meppiel, E. (2021). Neurological manifestations associated with SARS-CoV-2 and other coronaviruses: a narrative review for clinicians. Rev. Neurol. 177, 51-64. doi: 10.1016/j.neurol.2020.10.001

McChesney, M., and Oldstone, M. (1989). Virus-induced immunosuppression: infections with measles virus and human immunodeficiency virus. $A d v$. Immunol. 45, 335-380. doi: 10.1016/s0065-2776(08)60696-3

McDonald, C., Cahill, L., Ho, K., Yang, J., Kim, H., Silver, K., et al. (2015). Experimental malaria in pregnancy induces neurocognitive injury in uninfected offspring via a C5a-C5a receptor dependent pathway. PLoS Pathog. 11:e1005140. doi: 10.1371/journal.ppat.1005140

McDonald, C., Elphinstone, R., and Kain, K. (2013). The impact of placental malaria on neurodevelopment of exposed infants: a role for the complement system? Trends Parasitol. 29, 213-219. doi: 10.1016/j.pt.2013.03.005

McGovern, G., and Jeffrey, M. (2007). Scrapie-specific pathology of sheep lymphoid tissues. PLoS One. 2:e1304. doi: 10.1371/journal.pone.0001304

McGuire, J., Gill, A., Douglas, S., Kolson, D., and CNS HIV Antiretroviral Therapy Effects Research (Charter) Group (2016). The complement system, neuronal injury, and cognitive function in horizontally-acquired HIV-infected youth. J. Neurovirol. 22, 823-830. doi: 10.1007/s13365-016-0460-5

McQuaid, S., and Cosby, S. (2002). An immunohistochemical study of the distribution of the measles virus receptors, CD46 and SLAM, in normal human tissues and subacute sclerosing panencephalitis. Lab. Invest. 82, 403-409. doi: 10.1038/labinvest.3780434

Mécharles, S., Herrmann, C., Poullain, P., Tran, T., Deschamps, N., Mathon, G., et al. (2016). Acute myelitis due to Zika virus infection. Lancet 387:1481. doi: 10.1016/S0140-6736(16)00644-9

Mehlhop, E., Whitby, K., Oliphant, T., Marri, A., Engle, M., and Diamond, M. (2005). Complement activation is required for induction of a protective antibody response against West Nile virus infection. J. Virol. 79, 7466-7477. doi: 10.1128/JVI.79.12.7466-7477.2005
Mook-Kanamori, B., Geldhoff, M., van der Poll, T., and van de Beek, D. (2011). Pathogenesis and pathophysiology of pneumococcal meningitis. Clin. Microbiol. Rev. 24, 557-591. doi: 10.1128/CMR.00008-11

Morgan, B. (2015). The role of complement in neurological and neuropsychiatric diseases. Expert Rev. Clin. Immunol. 11, 1109-1119. doi: 10.1586/1744666X. 2015.1074039

Morgan, B. (2018). Complement in the pathogenesis of Alzheimer's disease. Semin. Immunopathol. 40, 113-124. doi: 10.1007/s00281-017-0662-9

Muk, T., Stensballe, A., Pankratova, S., Nguyen, D., Brunse, A., Sangild, P., et al. (2019). Rapid Proteome changes in plasma and cerebrospinal fluid following bacterial infection in preterm newborn pigs. Front. Immunol. 10:2651. doi: 10.3389/fimmu.2019.02651

Nataf, S., Stahel, P., Davoust, N., and Barnum, S. (1999). Complement anaphylatoxin receptors on neurons: new tricks for old receptors? Trends Neurosci. 22, 397-402. doi: 10.1016/s0166-2236(98)01390-3

Norris, G., Smirnov, I., Filiano, A., Shadowen, H., Cody, K., Thompson, J., et al. (2018). Neuronal integrity and complement control synaptic material clearance by microglia after CNS injury. J. Exp. Med. 215, 1789-1801. doi: 10.1084/jem. 20172244

Ogata, A., Czub, S., Ogata, S., Cosby, S., McQuaid, S., Budka, H., et al. (1997). Absence of measles virus receptor (CD46) in lesions of subacute sclerosing panencephalitis brains. Acta Neuropathol. 94, 444-449. doi: 10.1007/ s004010050731

Ólafsson, E., and Barragan, A. (2020). The unicellular eukaryotic parasite Toxoplasma gondii hijacks the migration machinery of mononuclear phagocytes to promote its dissemination. Biol. Cell 112, 239-250. doi: 10.1111/boc. 202000005

Oldstone, M., Lewicki, H., Thomas, D., Tishon, A., Dales, S., Patterson, J., et al. (1999). Measles virus infection in a transgenic model: virus-induced immunosuppression and central nervous system disease. Cell 98, 629-640. doi: 10.1016/s0092-8674(00)80050-1

Olivier, I., Cacabelos, R., and Naidoo, V. (2018). Risk factors and pathogenesis of HIV-associated neurocognitive disorder: the role of host genetics. Int. J. Mol. Sci. 19:3594. doi: 10.3390/ijms19113594

OSullivan, J., Preston, R., ORegan, N., and ODonnell, J. (2016). Emerging roles for hemostatic dysfunction in malaria pathogenesis. Blood 127, 2281-2288. doi: 10.1182/blood-2015-11-636464

Pais, T., and Penha-Gonçalves, C. (2019). Brain endothelium: the "innate immunity response hypothesis" in cerebral malaria pathogenesis. Front. Immunol. 9:3100. doi: $10.3389 /$ fimmu.2018.03100

Panackal, A., and Williamson, P. (2015). Fungal infections of the central nervous system. Continuum (Minneap. Minn) 21, 1662-1678. doi: 10.1212/CON. 0000000000000241

Pasupuleti, M., Walse, B., Nordahl, E., Mörgelin, M., Malmsten, M., and Schmidtchen, A. (2007). Preservation of antimicrobial properties of complement peptide C3a, from invertebrates to humans. J. Biol. Chem. 282, 2520-2528. doi: 10.1074/jbc.M607848200

Patel, S., Berghout, J., Lovegrove, F., Ayi, K., Conroy, A., Serghides, L., et al. (2008). C5 deficiency and C5a or C5aR blockade protects against cerebral malaria. J. Exp. Med. 205, 1133-1143. doi: 10.1084/jem.20072248

Perez-Alcazar, M., Daborg, J., Stokowska, A., Wasling, P., Björefeldt, A., Kalm, M., et al. (2014). Altered cognitive performance and synaptic function in the hippocampus of mice lacking C3. Exp Neurol. 253, 154-164. doi: 10.1016/j. expneurol.2013.12.013

Perlmutter, D., and Colten, H. (1986). Molecular immunobiology of complement biosynthesis: a model of single-cell control of effector-inhibitor balance. Annu. Rev. Immunol. 4, 231-251. doi: 10.1146/annurev.iy.04.040186.001311

Pian, Y., Gan, S., Wang, S., Guo, J., Wang, P., Zheng, Y., et al. (2012). Fhb, a novel factor H-binding surface protein, contributes to the antiphagocytic ability and virulence of Streptococcus suis. Infect. Immun. 80, 2402-2413. doi: 10.1128/IAI. 06294-11

Pittman, K., and Knoll, L. (2015). Long-Term relationships: the complicated interplay between the host and the developmental stages of Toxoplasma gondii during acute and chronic infections. Microbiol. Mol. Biol. Rev. 79, 387-401. doi: 10.1128/MMBR.00027-15

Pomares, C., Devillard, S., Holmes, T., Olariu, T., Press, C., Ramirez, R., et al. (2018). Genetic characterization of Toxoplasma gondii DNA samples isolated from humans living in North America: an unexpected high prevalence 
of atypical genotypes. J. Infect. Dis. 218, 1783-1791. doi: 10.1093/infdis/jiy 375

Pozo-Rodrigálvarez, A., Ollaranta, R., Skoog, J., Pekny, M., and Pekna, M. (2021). Hyperactive behavior and altered brain morphology in adult complement C3a receptor deficient mice. Front. Immunol. 12:604812. doi: 10.3389/fimmu.2021. 604812

Prusiner, S. (1998). Prions. Proc. Natl. Acad. Sci. U.S.A. 95, 13363-13383. doi: 10.1073/pnas.95.23.13363

Prusiner, S., Scott, M., DeArmond, S., and Cohen, F. (1998). Prion protein biology. Cell 93, 337-348. doi: 10.1016/s0092-8674(00)81163-0

Rahpeymai, Y., Hietala, M. A., Wilhelmsson, U., Fotheringham, A., Davies, I., Nilsson, A. K., et al. (2006). Complement: a novel factor in basal and ischemiainduced neurogenesis. EMBO J. 25, 1364-1374.

Rajasingham, R., Smith, R., Park, B., Jarvis, J., Govender, N., Chiller, T., et al. (2017). Global burden of disease of HIV-associated cryptococcal meningitis: an updated analysis. Lancet Infect. Dis. 17, 873-881. doi: 10.1016/S1473-3099(17)30243-8

Rall, G., Manchester, M., Daniels, L., Callahan, E., Belman, A., and Oldstone, M. (1997). A transgenic mouse model for measles virus infection of the brain. Proc. Natl. Acad. Sci. U.S.A. 94, 4659-4663. doi: 10.1073/pnas.94.9.4659

Rambach, G., Maier, H., Vago, G., Mohsenipour, I., Lass-Flörl, C., Defant, A., et al. (2008). Complement induction and complement evasion in patients with cerebral aspergillosis. Microbes Infect. 10, 1567-1576. doi: 10.1016/j.micinf. 2008.09.011

Ramos, T., Darley, M., Hu, X., Billker, O., Rayner, J., Ahras, M., et al. (2011). Cutting edge: the membrane attack complex of complement is required for the development of murine experimental cerebral malaria. J. Immunol. 186, 6657-6660. doi: 10.4049/jimmunol.1100603

Ramos, T., Darley, M., Weckbach, S., Stahel, P., Tomlinson, S., and Barnum, S. (2012). The C5 convertase is not required for activation of the terminal complement pathway in murine experimental cerebral malaria. J. Biol Chem. 287, 24734-24738. doi: 10.1074/jbc.C112.378364

Rasmussen, S., Jamieson, D., Honein, M., and Petersen, L. (2016). Zika virus and birth defects-reviewing the evidence for causality. N. Engl. J. Med. 374, 1981-1987. doi: 10.1056/NEJMsr1604338

Readhead, B., Haure-Mirande, J., Funk, C., Richards, M., Shannon, P., Haroutunian, V., et al. (2018). Multiscale analysis of independent Alzheimer's cohorts finds disruption of molecular, genetic, and clinical networks by human herpesvirus. Neuron 99, 64-82.e7. doi: 10.1016/j.neuron.2018. 05.023

Riggle, B., Miller, L., and Pierce, S. (2020). Desperately seeking therapies for cerebral malaria. J. Immunol. 204, 327-334. doi: 10.4049/jimmunol. 1900829

Robakis, N. (2020). What do recent clinical trials teach us about the etiology of AD. Adv. Exp. Med. Biol. 1195:167. doi: 10.1007/978-3-030-32633-3_23

Rogers, J., Cooper, N., Webster, S., Schultz, J., McGeer, P., Styren, S., et al. (1992). Complement activation by beta-amyloid in Alzheimer disease. Proc. Natl. Acad. Sci. U.S.A. 89, 10016-10020. doi: 10.1073/pnas.89.21.10016

Rosa, T., Flammersfeld, A., Ngwa, C., Kiesow, R., Fischer, P., Zipfel, P., et al. (2016). The Plasmodium falciparum blood stages acquire factor $\mathrm{H}$ family proteins to evade destruction by human complemen. Cell. Microbiol. 18, 573-590. doi: 10.1111/cmi.12535

Ross, S., and Densen, P. (1984). Complement deficiency states and infection: epidemiology, pathogenesis and consequences of neisserial and other infections in an immune deficiency. Medicine 63, 243-273.

Rostagno, A., Revesz, T., Lashley, T., Tomidokoro, Y., Magnotti, L., Braendgaard, H., et al. (2002). Complement activation in chromosome 13 dementias. Similarities with Alzheimer's disease. J. Biol. Chem. 277, 49782-49790. doi: 10.1074/jbc.M206448200

Rowe, J., Moulds, J., Newbold, C., and Miller, L. (1997). P. falciparum rosetting mediated by a parasite-variant erythrocyte membrane protein and complement-receptor 1. Nature 388, 292-295. doi: 10.1038/40888

Rubio-Perez, J., and Morillas-Ruiz, J. (2012). A review: inflammatory process in Alzheimer's disease, role of cytokines. ScientificWorldJournal 2012:756357. doi: $10.1100 / 2012 / 756357$

Ruhnke, M., Kofla, G., Otto, K., and Schwartz, S. (2007). CNS aspergillosis: recognition, diagnosis and management. CNS Drugs 21, 659-676. doi: 10.2165/ 00023210-200721080-00004
Russo, F., Jungmann, P., and Beltrão-Braga, P. (2017). Zika infection and the development of neurological defects. Cell Microbiol. 19:e12744. doi: 10.1111/ cmi. 12744

Russo, J., Bohenzky, R., Chien, M., Chen, J., Yan, M., Maddalena, D., et al. (1996). Nucleotide sequence of the Kaposi sarcoma-associated herpesvirus (HHV8). Proc. Natl. Acad. Sci. U.S.A. 93, 14862-14867. doi: 10.1073/pnas.93.25.14862

Sadek, J., Pergam, S., Harrington, J., Echevarria, L., Davis, L., Goade, D., et al. (2010). Persistent neuropsychological impairment associated with West Nile virus infection. J. Clin. Exp. Neuropsychol. 32, 81-87. doi: 10.1080/ 13803390902881918

Said, J., Tasaka, T., de Vos, S., and Koeffler, H. (1997). Kaposi's sarcoma-associated herpesvirus/human herpesvirus type 8 encephalitis in HIV-positive and negative individuals. AIDS 11, 1119-1122. doi: 10.1097/00002030-19970900000006

Sasai, M., Pradipta, A., and Yamamoto, M. (2018). Host immune responses to Toxoplasma gondii. Int. Immunol. 30, 113-119.

Saul, A., Lashley, T., Revesz, T., Holton, J., Ghiso, J., Coomaraswamy, J., et al. (2013). Abundant pyroglutamate-modified ABri and ADan peptides in extracellular and vascular amyloid deposits in familial British and Danish dementias. Neurobiol. Aging 34, 1416-1425. doi: 10.1016/j.neurobiolaging. 2012.11.014

Schafer, D., Lehrman, E., Kautzman, A., Koyama, R., Mardinly, A., Yamasaki, R., et al. (2012). Microglia sculpt postnatal neural circuits in an activity and complement-dependent manner. Neuron 74, 691-705. doi: 10.1016/j.neuron. 2012.03.026

Schartz, N., and Tenner, A. (2020). The good, the bad, and the opportunities of the complement system in neurodegenerative disease. J. Neuroinflammation 17:354. doi: 10.1186/s12974-020-02024-8

Schmidt, C., Kennedy, A., and Tham, W. (2015). More than just immune evasion: hijacking complement by Plasmodium falciparum. Mol. Immunol. 67, 71-84. doi: 10.1016/j.molimm.2015.03.006

Schmutzhard, E., and Gerstenbrand, F. (1984). Cerebral malaria in Tanzania. Its epidemiology, clinical symptoms and neurological long term sequelae in the light of 66 cases. Trans R. Soc. Trop. Med. Hyg. 78, 351-353. doi: 10.1016/00359203(84)90118-4

Schneider, M., Prosser, B., Caesar, J., Kugelberg, E., Li, S., Zhang, Q., et al. (2009). Neisseria meningitidis recruits factor $\mathrm{H}$ using protein mimicry of host carbohydrates. Nature 458, 890-893. doi: 10.1038/nature07769

Schreiber, R., and Feldman, H. (1980). Identification of the activator system for antibody to Toxoplasma as the classical complement pathway. J. Infect. Dis. 141, 366-369. doi: 10.1093/infdis/141.3.366

Sejvar, J., Haddad, M., Tierney, B., Campbell, G., Marfin, A., Van Gerpen, J., et al. (2003). Neurologic manifestations and outcome of West Nile virus infection. JAMA 290, 511-515. doi: 10.1001/jama.290.4.511

Sekar, A., Bialas, A., de Rivera, H., Davis, A., Hammond, T., Kamitaki, N., et al. (2016). Schizophrenia risk from complex variation of complement component 4. Nature 530, 177-183. doi: 10.1038/nature16549

Serafini, B., Rosicarelli, B., Franciotta, D., Magliozzi, R., Reynolds, R., Cinque, P., et al. (2007). Dysregulated Epstein-Barr virus infection in the multiple sclerosis brain. J. Exp. Med. 204, 2899-2912.

Shi, Q., Chowdhury, S., Ma, R., Le, K., Hong, S., Caldarone, B., et al. (2017). Complement $\mathrm{C} 3$ deficiency protects against neurodegeneration in aged plaquerich APP/PS1 mice. Sci. Transl. Med. 9:eaaf6295. doi: 10.1126/scitranslmed. aaf6295

Shi, Q., Colodner, K., Matousek, S., Merry, K., Hong, S., Kenison, J., et al. (2015). Complement C3-deficient mice fail to display age-related hippocampal decline. J. Neurosci. 35, 13029-13042. doi: 10.1523/JNEUROSCI.1698-15.2015

Shinjyo, N., Hikosaka, K., Kido, Y., Yoshida, H., and Norose, K. (2021). Toxoplasma infection induces sustained up-regulation of complement factor B and $\mathrm{C} 5 \mathrm{a}$ receptor in the mouse brain via microglial activation: implication for the alternative complement pathway activation and anaphylatoxin signaling in cerebral toxoplasmosis. Front. Immunol. 11:603924. doi: 10.3389/fimmu.2020. 603924

Shinjyo, N., Stahlberg, A., Dragunow, M., Pekny, M., and Pekna, M. (2009). Complement-derived anaphylatoxin C3a regulates in vitro differentiation and migration of neural progenitor cells in vitro. Stem Cells 27, 2824-2832. doi: $10.1002 /$ stem. 225 
Sikorski, P., Commodaro, A., and Grigg, M. (2020). Toxoplasma gondii recruits factor $\mathrm{H}$ and $\mathrm{C} 4 \mathrm{~b}$-Binding protein to mediate resistance to serum killing and promote parasite persistence in vivo. Front. Immunol. 10:3105. doi: 10.3389/ fimmu.2019.03105

Silamut, K., Phu, N., Whitty, C., Turner, G., Louwrier, K., Mai, N., et al. (1999). A quantitative analysis of the microvascular sequestration of malaria parasites in the human brain. Am. J. Pathol. 155, 395-410. doi: 10.1016/S0002-9440(10) 65136-X

Silva-Barrios, S., and Stäger, S. (2017). Protozoan parasites and type I IFNs. Front. Immunol. 8:14. doi: 10.3389/fimmu.2017.00014

Singh, G., Angwafor, S., Njamnshi, A., Fraimow, H., and Sander, J. (2020). Zoonotic and vector-borne parasites and epilepsy in low-income and middle-income countries. Nat. Rev. Neurol. 16, 333-345. doi: 10.1038/s41582-020-0361-3

Skaper, S. (2012). Alzheimer's disease and amyloid: culprit or coincidence? Int. Rev. Neurobiol. 102, 277-316. doi: 10.1016/B978-0-12-386986-9.00011-9

Souza, I., Barros-Aragão, F., Frost, P., Figueiredo, C., and Clarke, J. (2019). Late neurological consequences of Zika Virus infection: risk factors and pharmaceutical approaches. Pharmaceuticals 12:60. doi: 10.3390/ph12020060

Spadafora, C., Awandare, G., Kopydlowski, K., Czege, J., Moch, J., Finberg, R., et al. (2010). Complement receptor 1 is a sialic acid-independent erythrocyte receptor of Plasmodium falciparum. PLoS Pathog. 6:e1000968. doi: 10.1371/ journal.ppat.1000968

Speth, C., Dierich, M., and Gasque, P. (2002). Neuroinvasion by pathogens: a key role of the complement system. Mol. Immunol. 38, 669-679. doi: 10.1016/ s0161-5890(01)00104-3

Speth, C., Williams, K., Hagleitner, M., Westmoreland, S., Rambach, G., Mohsenipour, I., et al. (2004). Complement synthesis and activation in the brain of SIV-infected monkeys. J. Neuroimmunol. 151, 45-54. doi: 10.1016/j. jneuroim.2004.02.013

Sprong, T., Roos, D., Weemaes, D., Neeleman, C., Geesing, C., Mollnes, T., et al. (2006). Deficient alternative complement pathway activation due to factor D deficiency by 2 novel mutations in the complement factor $\mathrm{D}$ gene in a family with meningococcal infections. Blood 107, 4865-4870. doi: 10.1182/blood2005-07-2820

Stahel, P., Frei, K., Fontana, A., Eugster, H., Ault, B., and Barnum, S. (1997). Evidence for intrathecal synthesis of alternative pathway complement activation proteins in experimental meningitis. Am. J. Pathol. 151, 897-904.

Stepanova, E., Kondrashin, A., Sergiev, V., Morozova, L., Turbabina, N., Maksimova, M., et al. (2019). Toxoplasmosis and mental disorders in the Russian Federation (with special reference to schizophrenia). PLoS One 14:e0219454. doi: 10.1371/journal.pone.0219454

Stevens, B., Allen, N. J., Vazquez, L. E., Howell, G. R., Christopherson, K. S., Nouri, N., et al. (2007). The classical complement cascade mediates CNS synapse elimination. Cell 131, 1164-1178. doi: 10.1016/j.cell.2007.10.036

Stokowska, A., Atkins, A., Morán, J., Pekny, T., Bulmer, L., Pascoe, M., et al. (2017). Complement peptide C3a stimulates neural plasticity after experimental brain ischemia. Brain 140, 353-369. doi: 10.1093/brain/aww314

Stokowska, A., and Pekna, M. (2018). "Complement C3a: shaping the plasticity of the post-stroke brain," in Cellular and Molecular Approaches to Regeneration and Repair. Springer Series in Translational Stroke Research, eds P. Lapchak and J. Zhang (Cham: Springer), 521-541. doi: 10.1007/978-3-319-66679-2_26

Storch, M., Piddlesden, S., Haltia, M., Iivanainen, M., Morgan, P., and Lassmann, H. (1998). Multiple sclerosis: in situ evidence for antibody- and complement-mediated demyelination. Ann. Neurol. 43, 465-471. doi: 10.1002/ ana.410430409

Stracciari, A., Bottini, G., Guarino, M., Magni, E., Pantoni, L., and "Cognitive and Behavioral Neurology” Study Group of the Italian Neurological Society (2021). Cognitive and behavioral manifestations in SARS-CoV-2 infection: not specific or distinctive features? Neurol Sci. 42, 2273-2281. doi: 10.1007/s10072-02105231-0

Sun, D., Zhang, M., Liu, G., Wu, H., Li, C., Zhou, H., et al. (2016). Intravascular clearance of disseminating Cryptococcus neoformans in the brain can be improved by enhancing neutrophil recruitment in mice. Eur. J. Immunol. 46, 1704-1714. doi: 10.1002/eji.201546239

Taniguchi, Y., Appiah-Kwarteng, C., Murakami, M., Fukumoto, J., Nagamune, K., Matsuo, T., et al. (2018). Atypical virulence in a type III Toxoplasma gondii strain isolated in Japan. Parasitol. Int. 67, 587-592.
Tenner, A. (2020). Complement-mediated events in Alzheimer's disease: mechanisms and potential therapeutic targets. J. Immunol. 204, 306-315. doi: 10.4049/jimmunol.1901068

Tenner, A., Stevens, B., and Woodruff, T. (2018). New tricks for an ancient system: physiological and pathological roles of complement in the CNS. Mol. Immunol. 102, 3-13. doi: 10.1016/j.molimm.2018.06.264

Tham, W., Wilson, D., Lopaticki, S., Schmidt, C., Tetteh-Quarcoo, P., Barlow, P., et al. (2010). Complement receptor 1 is the host erythrocyte receptor for Plasmodium falciparum PfRh4 invasion ligand. Proc. Natl. Acad. Sci. U.S.A. 107, 17327-17332. doi: 10.1073/pnas.1008151107

Tso, F., Sawyer, A., Kwon, E., Mudenda, V., Langford, D., Zhou, Y., et al. (2017). Kaposi's sarcoma-associated herpesvirus infection of neurons in HIV-positive patients. J. Infect. Dis. 215, 1898-1907. doi: 10.1093/infdis/ jiw545

Tuite, A., Elias, M., Picard, S., Mullick, A., and Gros, P. (2005). Genetic control of susceptibility to Candida albicans in susceptible A/J and resistant C57BL/6 J mice. Genes Immun. 6, 672-682. doi: 10.1038/sj.gene.6364254

Tyebji, S., Seizova, S., Garnham, A., Hannan, A., and Tonkin, C. (2019a). Impaired social behaviour and molecular mediators of associated neural circuits during chronic Toxoplasma gondii infection in female mice. Brain Behav. Immun. 80, 88-108. doi: 10.1016/j.bbi.2019.02.028

Tyebji, S., Seizova, S., Hannan, A., and Tonkin, C. (2019b). Toxoplasmosis: a pathway to neuropsychiatric disorder. Neurosci. Biobehav. Rev. 96, 72-92. doi: 10.1016/j.neubiorev.2018.11.012

van de Beek, D., Brouwer, M., Hasbun, R., Koedel, U., Whitney, C., and Wijdicks, E. (2016). Community-acquired bacterial meningitis. Nat. Rev. Dis. Primers 2:16074. doi: $10.1038 /$ nrdp.2016.74

van de Beek, D., de Gans, J., Spanjaard, L., Weisfelt, M., Reitsma, J., and Vermeulen, M. (2004). Clinical features, complications, and outcome in adults with pneumococcal meningitis: a prospective case series. N. Engl. J. Med. 351, 1849-1859. doi: 10.1056/NEJMoa040845

Van der Heyde, H., Nolan, J., Combes, V., Gramaglia, I., and Grau, G. (2006). A unified hypothesis for the genesis of cerebral malaria: sequestration, inflammation and hemostasis leading to microcirculatory dysfunction. Trends Parasitol. 22, 503-508. doi: 10.1016/j.pt.2006.09.002

Vasek, M., Garber, C., Dorsey, D., Durrant, D., Bollman, B., Soung, A., et al. (2016). A complement-microglial axis drives synapse loss during virus-induced memory impairment. Nature 534, 538-543. doi: 10.1038/ nature 18283

Veerhuis, R., Nielsen, H., and Tenner, A. (2011). Complement in the brain. Mol. Immunol. 48, 1592-1603. doi: 10.1016/j.molimm.2011.04.003

Villegas, M., Sciutto, E., Rosetti, M., Fleury, A., and Fragoso, G. (2019). Association of TRAF1/C5 locus polymorphisms with epilepsy and clinical traits in mexican patients with neurocysticercosis. Infect Immun. 87, e347-e319. doi: 10.1128/ IAI.00347-19

Virgin, H. IV, Latreille, P., Wamsley, P., Hallsworth, K., Weck, K., Dal Canto, A., et al. (1997). Complete sequence and genomic analysis of murine gammaherpesvirus 68. J. Virol. 71, 5894-5904. doi: 10.1128/JVI.71.8.5894-5904. 1997

Wassmer, S., de Souza, J., Frère, C., Candal, F., Juhan-Vague, I., and Grau, G. (2006). TGF-betal released from activated platelets can induce TNF-stimulated human brain endothelium apoptosis: a new mechanism for microvascular lesion during cerebral malaria. J. Immunol. 176, 1180-1184. doi: 10.4049/ jimmunol.176.2.1180

Wassmer, S., and Grau, G. (2017). Severe malaria: what's new on the pathogenesis front? Int. J. Parasitol. 47, 145-152. doi: 10.1016/j.ijpara.2016.08.002

Weaver, S., and Barrett, A. (2004). Transmission cycles, host range, evolution and emergence of arboviral disease. Nat. Rev. Microbiol. 2, 789-801. doi: 10.1038/ nrmicro1006

Weaver, S., Ferro, C., Barrera, R., Boshell, J., and Navarro, J. (2004). Venezuelan equine encephalitis. Annu. Rev. Entomol. 49, 141-174. doi: 10.1146/annurev. ento.49.061802.123422

WHO (2019). Dementia Fact sheet. Geneva: WHO.

Woehrl, B., Brouwer, M., Murr, C., Heckenberg, S., Baas, F., Pfister, H., et al. (2011). Complement component 5 contributes to poor disease outcome in humans and mice with pneumococcal meningitis. J. Clin. Invest. 121, 3943-3953. doi: 10.1172/JCI57522 
Woodruff, T. M., Ager, R. R., Tenner, A. J., Noakes, P. G., and Taylor, S. M. (2010). The role of the complement system and the activation fragment C5a in the central nervous system. Neuromolecular Med. 12, 179-192.

Woollard, S., Bhargavan, B., Yu, F., and Kanmogne, G. (2014). Differential effects of Tat proteins derived from HIV-1 subtypes B and recombinant CRF02_AG on human brain microvascular endothelial cells: implications for blood-brain barrier dysfunction. J. Cereb. Blood Flow Metab. 34, 1047-1059. doi: 10.1038/ jcbfm.2014.54

Wu, K., Zhang, T., Zhao, G., Ma, N., Zhao, S., Wang, N., et al. (2019). The $\mathrm{C} 3 \mathrm{a} / \mathrm{C} 3 \mathrm{aR}$ axis mediates anti-inflammatory activity and protects against uropathogenic E coli-induced kidney injury in mice. Kidney Int. 96, 612-627. doi: 10.1016/j.kint.2019.03.005

Wu, M., Brennan, F., Lynch, J., Mantovani, S., Phipps, S., Wetsel, R., et al. (2013). The receptor for complement component C3a mediates protection from intestinal ischemia-reperfusion injuries by inhibiting neutrophil mobilization. Proc. Natl. Acad. Sci. U.S.A. 110, 9439-9444. doi: 10.1073/pnas.1218815110

Wyss-Coray, T., Yan, F., Lin, A., Lambris, J., Alexander, J., Quigg, R., et al. (2002). Prominent neurodegeneration and increased plaque formation in complementinhibited Alzheimer's mice. Proc. Natl. Acad. Sci. U.S.A. 99, 10837-10842. doi: 10.1073/pnas.162350199

Xiao, J., Li, Y., Gressitt, K., He, H., Kannan, G., Schultz, T., et al. (2016). Cerebral complement Clq activation in chronic Toxoplasma infection. Brain Behav. Immun. 58, 52-56. doi: 10.1016/j.bbi.2016.04.009

Yanamadala, V., and Friedlander, R. (2010). Complement in neuroprotection and neurodegeneration. Trends Mol. Med. 16, 69-76. doi: 10.1016/j.molmed.2009. 12.001

Yuan, X., Shan, M., You, R., Frazier, M. V., Hong, M. J., Wetsel, R. A., et al. (2015). Activation of C3a receptor is required in cigarette smoke-mediated emphysema. Mucosal Immunol. 8, 874-885. doi: 10.1038/mi.2014.118
Yusuf, F., Hafiz, M., Shoaib, M., and Ahmed, S. (2017). Cerebral malaria: insight into pathogenesis, complications and molecular biomarkers. Infect. Drug Resist. 10, 57-59. doi: 10.2147/IDR.S125436

Zhang, J., Malik, A., Choi, H., Ko, R., Dissing-Olesen, L., and MacVicar, B. (2014). Microglial CR3 activation triggers long-term synaptic depression in the hippocampus via NADPH oxidase. Neuron 82, 195-207. doi: 10.1016/j.neuron. 2014.01.043

Zwijnenburg, P., van der Poll, T., Florquin, S., Polfliet, M., van den Berg, T., Dijkstra, C., et al. (2007). C1 inhibitor treatment improves host defense in pneumococcal meningitis in rats and mice. J. Infect. Dis. 196, 115-123. doi: $10.1086 / 518609$

Conflict of Interest: The authors declare that the research was conducted in the absence of any commercial or financial relationships that could be construed as a potential conflict of interest.

Publisher's Note: All claims expressed in this article are solely those of the authors and do not necessarily represent those of their affiliated organizations, or those of the publisher, the editors and the reviewers. Any product that may be evaluated in this article, or claim that may be made by its manufacturer, is not guaranteed or endorsed by the publisher.

Copyright (c) 2021 Shinjyo, Kagaya and Pekna. This is an open-access article distributed under the terms of the Creative Commons Attribution License (CC BY). The use, distribution or reproduction in other forums is permitted, provided the original author(s) and the copyright owner(s) are credited and that the original publication in this journal is cited, in accordance with accepted academic practice. No use, distribution or reproduction is permitted which does not comply with these terms. 